\title{
High-temperature deformation during continental-margin subduction \& exhumation: The ultrahigh-pressure Western Gneiss Region of Norway
}

\author{
Bradley R. Hacker ${ }^{\text {a }}$, Torgeir B. Andersen ${ }^{\text {b }}$, Scott Johnston ${ }^{\mathrm{a}, 1}$, Andrew R.C. Kylander-Clark ${ }^{\mathrm{a}}$, \\ Emily M. Peterman ${ }^{\mathrm{a}, 2}$, Emily O. Walsh ${ }^{\mathrm{a}, 3}$, David Young ${ }^{\mathrm{a}, *, 4}$ \\ a Department of Earth Science, University of California, Santa Barbara, CA 93106, USA \\ b Universitetet i Oslo, Department of Geosciences, P.O. Box 1047 Blindern, 0316 Oslo, Norway
}

\begin{abstract}
A B S T R A C T
A new dataset for the high-pressure to ultrahigh-pressure Western Gneiss Region allows the definition of distinct structural and petrological domains. Much of the study area is an E-dipping homocline with E-plunging lineations that exposes progressively deeper, more strongly deformed, more eclogite-rich structural levels westward. Although eclogites crop out across the WGR, Scandian deformation is weak and earlier structures are well preserved in the southeastern half of the study area. The Scandian reworking increases westward, culminating in strong Scandian fabrics with only isolated pockets of older structures; the dominant Scandian deformation was coaxial E-W stretching. The sinistrally sheared Møre-Trøndelag Fault Complex and Nordfjord Mylonitic Shear Zone bound these rocks to the north and south. There was moderate top-E, amphibolite-facies deformation associated with translation of the allochthons over the basement along its eastern edge, and the Nordfjord-Sogn Detachment Zone underwent strong lower amphibolite-facies to greenschist-facies top-W shearing. A northwestward increase in exhumation-related melting is indicated by leucosomes with hornblende, plagioclase, and Scandian sphene. In the western $2 / 3$ of the study area, exhumation-related, amphibolite-facies symplectite formation in quartzofeldspathic gneiss postdated most Scandian deformation; further deformation was restricted to slip along biotite-rich foliation planes and minor local folding. That the Western Gneiss Region quartzofeldspathic gneiss exhibits a strong gradient in degree of deformation, implies that continental crust in general need not undergo pervasive deformation during subduction.
\end{abstract}

\section{Introduction}

How continental crust is exhumed from ultrahigh-pressure depths remains one of the most intriguing tectonic problems. An excellent place to study ultrahigh-pressure (UHP) rocks and their exhumation is the Western Gneiss Region (WGR) of Norway, where the $\sim 5000 \mathrm{~km}^{2}$ Caledonian UHP terrane is surrounded to the north, east and south by associated high-pressure rocks covering $30,000 \mathrm{~km}^{2}$ (Fig. 1). This paper integrates structural geology and structural petrology from a geologic transect across the WGR to address four large-scale questions: i) What was the volume of rock that was exhumed from (U)HP conditions?

\footnotetext{
${ }^{1}$ Now at the Department of Physics, California Polytechnic State University, San Luis Obispo, CA, 93407, USA

2 Now at the Department of Earth and Planetary Sciences, University of California, Santa Cruz, CA 95064, USA.

${ }^{3}$ Now at the Department of Geology, Cornell College, Mount Vernon, IA, 52314, USA

${ }^{4}$ Now at the Department of Geology, University of Texas, San Antonio, TX, 78249, USA.
}

Assessing the scale of (U)HP metamorphism assists in defining the tectonic setting in which (U)HP tectonism occurs and the magnitude of its impact on Earth evolution. ii) How was deformation partitioned throughout the (U)HP terrane during subduction and exhumation-i.e., were the (U)HP rocks subducted and exhumed as a coherent and intact sheet or did they disaggregate/delaminate during subduction and/ or exhumation? iii) How did deformation vary temporally, from the beginning of subduction to the end of exhumation-e.g., did intense deformation mark the entire subduction and exhumation cycle? iv) What was the relationship between deformation and metamorphism during subduction and exhumation-e.g., did deformation and metamorphism occur in stages or were they continuous and coeval during exhumation?

To address these questions, this paper presents outcrop to thinsection observations of structures and metamorphic minerals. It begins with an overview of the study area; explains how various deformation and metamorphic events can be distinguished; characterizes the eclogite-, granulite-, and amphibolite-facies structures; describes various structural domains; and ends with a discussion of the implications for the questions posed above. 


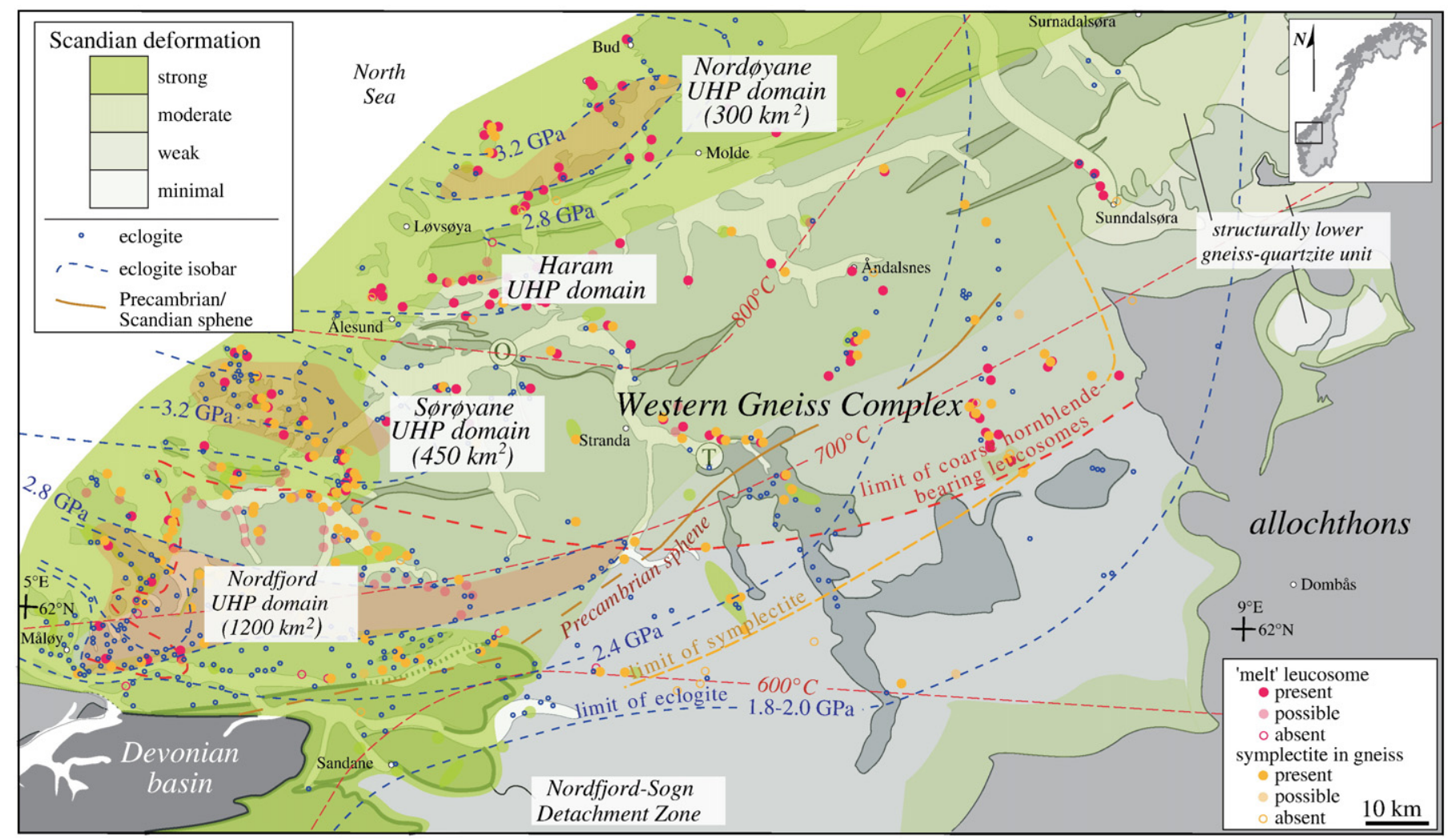

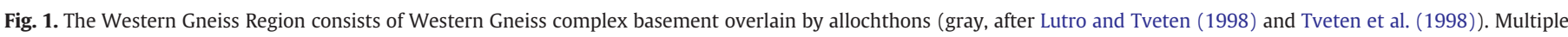

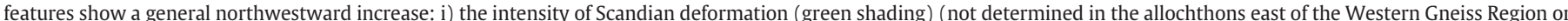

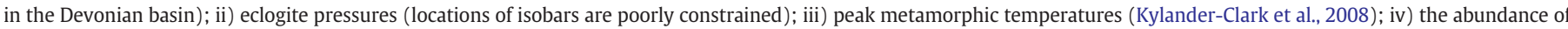

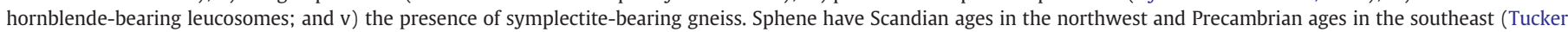

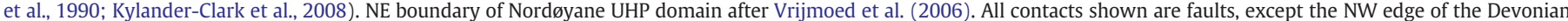
basin.

\subsection{The Western Gneiss Region}

The Western Gneiss Region (Fig. 1) is composed of Proterozoic Fennoscandian gneisses (chiefly orthogneisses from c. $1650 \mathrm{Ma}$ and $950 \mathrm{Ma}$ ) (cf. Austrheim et al., 2003; Skår and Pedersen, 2003), often referred to as the Western Gneiss Complex (WGC), overlain by continental and oceanic allochthons (see below). The early Paleozoic orogeny during which these units were deformed, metamorphosed, and juxtaposed is the Caledonian Orogeny (Fig. 2). The final stage of this orogeny-called the Scandian Orogeny-included the following: i) closure of the Iapetus ocean and emplacement of allochthons onto Baltica from 430 to $410 \mathrm{Ma}$ (Tucker et al., 2004; Hacker and Gans, 2005); ii) Baltica-Laurentia collision and westward subduction of the Baltica basement and portions of the allochthons to ultrahighpressure depths from 425 to 400 Ma (Andersen et al., 1991; Andersen, 1998; Bingen et al., 2004; Root et al., 2004; Terry and Robinson, 2004; Root et al., 2005; Kylander-Clark et al., 2007; Kylander-Clark et al., 2008); and iii) exhumation to shallow crustal levels from $\sim 400$ to 385 Ma (Andersen, 1998; Terry et al., 2000a; Tucker et al., 2004; Hacker, 2007; Walsh et al., 2007). The WGC is locally imbricated with Caledonian nappe units-as suggested by the presence of a structurally lower gneiss-quartzite unit (Gee, 1980; Krill, 1980) in the northeastern part of the study area (Storli thrust of Tucker et al., 2004) (Fig. 1)-but the main parts of the WGR is autochthonous as shown by the continuous exposures below the nappes across from the foreland to the hinterland region.

The most common rock type of the WGC in the study area is biotite \pm hornblende \pm garnet tonalitic and granodioritic gneiss with $5-80 \%$ (typically 20-40\%) cm-scale granitic leucosomes (Gjelsvik, 1951; Bryhni, 1966; Dransfield, 1994). This tonalitic gneiss grades with increasing K-feldspar abundance into biotite granitic gneiss that underlies $\sim 10 \%$ of the study area, and with increasing muscovite into a two-mica tonalitic gneiss that comprises $~ 5 \%$. All these rock types are cut by pegmatitic biotite-bearing granite dikes and all contain meter- to millimeter-scale blocks and layers of mafic rock: biotite gneiss, amphibolite and/or eclogite (Eskola, 1921) (the mineralogy depends on bulk composition, block/layer size, and degree of retrogression). Subordinate rock types include quartzite, carbonate, anorthosite, gabbro, garnet-mica gneiss, and peridotite (Gjelsvik, 1951; Bryhni, 1966; Dransfield, 1994; Robinson, 1995).

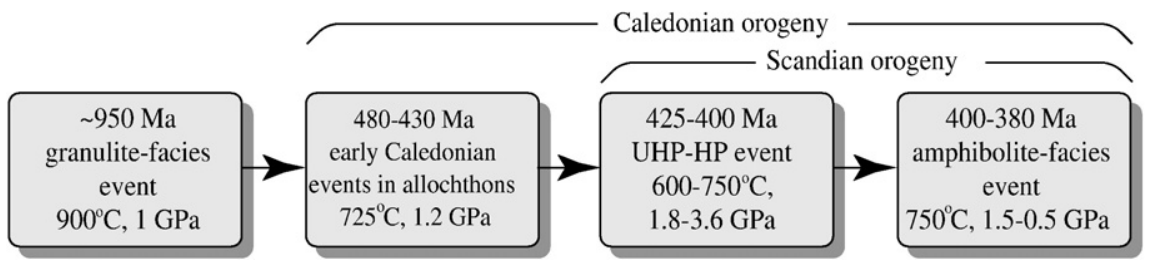

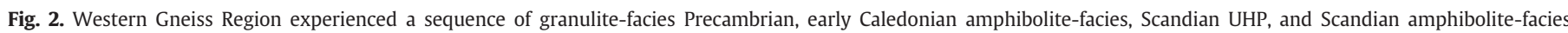
metamorphic-deformation events. 
The WGC is structurally overlain by discontinuous remnants of the Caledonian allochthons thrust southeastward over the autochthon during the early part of the Scandian orogeny (Gee, 1975). These allochthons are best exposed east of the WGR and include quartzites, muscovite-bearing gneisses, megacrystic augen gneisses, anorthositicgabbroic gneisses, garnet amphibolites, and garnet-mica schists (Fig. 1). These allochthons can be traced westward across the WGR along the northern part of Fig. 1 (Surnadalsøra to Løvsøya, Robinson, 1995); similar rocks crop out discontinuously across the WGR farther south in the area of Fig. 1 (Walsh and Hacker, 2004; Root et al., 2005; Johnston et al., 2007b).

\subsubsection{Metamorphic overview of the Western Gneiss Region}

The WGR is a polymetamorphic terrane in which the sequence of metamorphic events is relatively well understood (Bryhni and Andréasson, 1985) (Figs. 2 and 3) due to incomplete overprinting reactions. An amphibolite- to granulite-facies metamorphism at c. 950 Ma was associated with extensive plutonism and reached peak conditions of $\sim 800-900{ }^{\circ} \mathrm{C}$ and $1.0 \mathrm{GPa}$ (e.g., Cohen et al., 1988; Tucker et al., 1990; Krabbendam et al., 2000; Kühn et al., 2000; Bingen et al., 2001; Wain et al., 2001; Corfu and Andersen, 2002; Skår and Pedersen, 2003; Røhr et al., 2004; Root et al., 2005; Glodny et al., 2008). Decameter- to kilometer-scale relicts of this event (Krabbendam et al., 2000) comprise $~ 1 \%$ of the WGC, but are more common in continental allochthons that were thrust over the Baltica basement at an early stage of the collision (Jolivet et al., 2005). The local survival of these granulite-facies assemblages through subsequent overprinting episodes is attributed to low $\mathrm{H}_{2} \mathrm{O}$ activity, coarse grain size, and lack of deformation (Austrheim, 1987; Krabbendam et al., 2000).

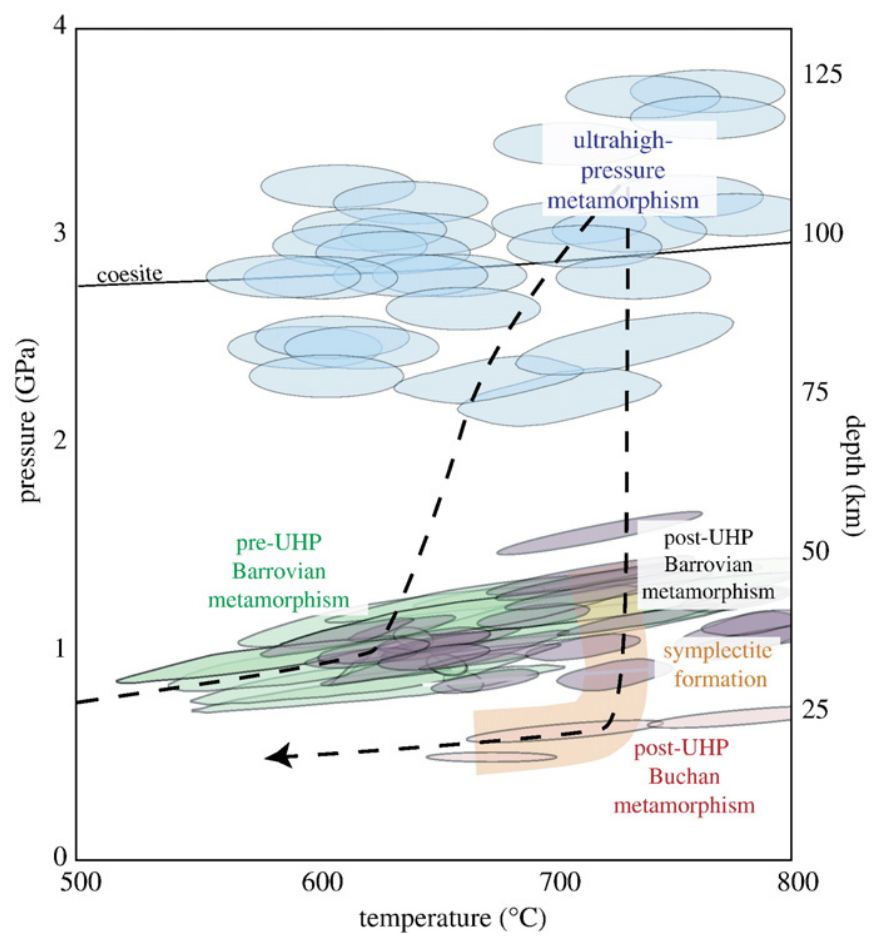

Fig. 3. Ultrahigh-pressure metamorphism in the Western Gneiss Region was likely preceded by the Barrovian 1 GPa metamorphism seen in the allochthons (Hacker and Gans, 2005), and was followed by Barrovian metamorphism beginning at $\sim 1.2 \mathrm{GPa}$ and then by Buchan metamorphism at $\sim 0.5 \mathrm{GPa}$ (ellipses show PT conditions for metamorphism summarized in Hacker, 2007); the 950 Ma granulite-facies metamorphism is not shown. Breakdown of K-white mica + garnet + Na-plagioclase to plagioclase + biotite symplectite was widespread in the western WGR during the postUHP Barrovian metamorphism (Peterman et al., in press). The PT path shown is schematic and pertains most closely to the UHP domains.
One or more episodes of greenschist- to amphibolite-facies metamorphism, peaking at $\sim 725^{\circ} \mathrm{C}$ and $1.2 \mathrm{GPa}$, occurred during the preScandian phases of the Caledonian Orogeny between 480 and $430 \mathrm{Ma}$ in the allochthons east of the WGR (Gee, 1975; Hacker and Gans, 2005); this event has not been recognized in the WGC. The Caledonian UHP metamorphism (Smith, 1984) that makes the WGR such an exciting scientific subject reached peak metamorphic conditions of $800{ }^{\circ} \mathrm{C}$ and 3.6 GPa (Lappin and Smith, 1978; see summary in Hacker, 2006) between 420 and 400 Ma (see summary in Kylander-Clark et al., 2007). Mafic bulk compositions suitable for forming eclogite make up $~ 2 \%$ of the WGR; northwest of the 'eclogite-in' isograd (Fig. 1), perhaps $70-90 \%$ (?) of such mafic rocks did transform to eclogite, with the rest remaining unreacted (Straume and Austrheim, 1999; Krabbendam et al., 2000; Walsh and Hacker, 2004). A Barrovian to Buchan amphibolite-facies overprint-with local partial meltingoccurred at $650-800^{\circ} \mathrm{C}$ during post-UHP decompression from $>1.5 \mathrm{GPa}$ to $\sim 0.5 \mathrm{GPa}$, almost completely obliterating the record of (U)HP metamorphism (Krogh, 1980; Chauvet et al., 1992; Dransfield, 1994; Straume and Austrheim, 1999; Hacker et al., 2003b; Terry and Robinson, 2003; Labrousse et al., 2004; Walsh and Hacker, 2004; Root et al., 2005; Engvik et al., 2007). Importantly, this metamorphic history documents that the UHP rocks were exhumed nearly isothermally to depths of $15-20 \mathrm{~km}$. $\mathrm{U}-\mathrm{Pb}$ sphene ages show that melting associated with this metamorphism occurred around $398 \mathrm{Ma}$ in the center of the study area and around $389 \mathrm{Ma}$ along the northwestern edge (Tucker et al., 2004; Kylander-Clark et al., 2008). Muscovite ${ }^{40} \mathrm{Ar} /{ }^{39} \mathrm{Ar}$ ages show cooling through $\sim 400{ }^{\circ} \mathrm{C}$ along the eastern edge of the WGR at $400 \mathrm{Ma}$ and along the northwestern edge by $385 \mathrm{Ma}$; the cores of the UHP domains have younger muscovite ages down to $375 \mathrm{Ma}$ (see summary in Hacker, 2007). Notably, the difference in sphene and muscovite ages is 4-5 Myr, implying $300-400{ }^{\circ} \mathrm{C}$ cooling at a rate of $>50{ }^{\circ} \mathrm{C} / \mathrm{Myr}$.

\subsubsection{Structural overview of the WGR}

The WGR has a complex deformation history to match the metamorphic record. The Precambrian (c. $950 \mathrm{Ma}$ ) amphibolite- to granulite-facies rocks and associated plutons vary from undeformed to strongly deformed (Austrheim and Griffin, 1985). In general, Precambrian fabrics are best preserved in the southeastern part of the study area (Fig. 1; see below), but there are enclaves of preserved Precambrian structures and igneous protoliths throughout the study area-even in the far west where Scandian deformation was most intense (Krabbendam et al., 2000). Scandian eclogite-facies structures are preserved in scattered bodies of eclogite across the WGR in the study area and farther south (Andersen et al., 1994; Krabbendam and Wain, 1997; Lund and Austrheim, 2003; Terry and Robinson, 2004; Foreman et al., 2005; Engvik et al., 2007). Early brittle eclogite-facies structures such as eclogite-facies pseudotachylites are preserved locally (Lund and Austrheim, 2003; John et al., 2009), but the eclogite tectonites are dominated by foliations, lineations and folds formed during ductile deformation. Scandian amphibolite-facies structures are, however, predominant throughout the WGR (Fig. 4). They consist mostly of gently plunging ENE-WSW to ESE-WNW lineations, isoclinal lineationparallel folds, and generally symmetrical fabrics implying coaxial strain histories with a constrictional component (Andersen et al., 1994; Dransfield, 1994; Krabbendam and Wain, 1997; Krabbendam and Dewey, 1998; Labrousse et al., 2002; Hacker et al., 2003a; Terry and Robinson, 2003; Engvik et al., 2007; Barth et al., 2010). Along the western edge of the WGR, these fabrics are overprinted by or merge into the Nordfjord-Sogn Detachment Zone (NSDZ), an amphibolite- to greenschist-facies, W-dipping, top-W shear zone that formed toward the end of the Scandian orogeny (Norton, 1987; Andersen and Jamtveit, 1990; see summary in Johnston et al., 2007a).

\subsubsection{Deciphering the polyphase history}

These multiple metamorphic and deformational events make it difficult to ascertain the history of any given kilometer- to millimeter- 


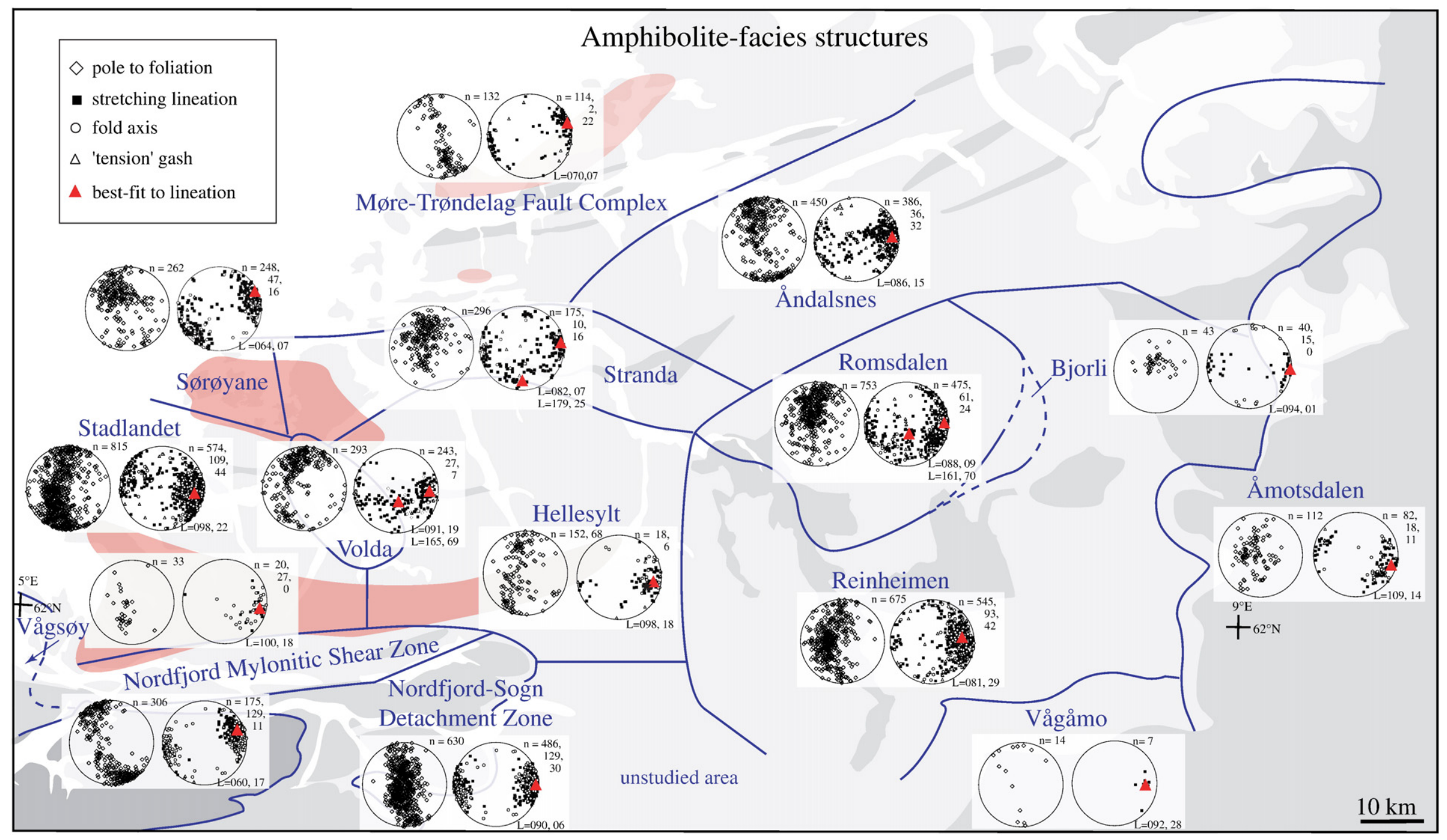

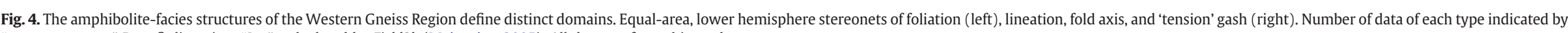
" $n=\ldots, \ldots, \ldots, \ldots$.. Best-fit lineation, " $L=$ ", calculated by Field $2 k$ (Mainprice, 2005). All data are from this study. 
scale structure, but such determinations are necessary to unravel the questions posed in the introduction. There are numerous ways to assess the sequence of events and to place structures at individual outcrops in a regional context. 1) Outcrop-scale overprinting relationships are the most direct means of establishing the relative timing of events. The most typical overprinting relationship in the WGR is that amphibolite-facies structures-such as boudin necks, strain shadows, recrystallized tails, and hydrated, deformed zones-fringe eclogite blocks (Terry and Robinson, 2003; Engvik et al., 2007). Also well known are eclogite-facies overprints on granulite-facies assemblages (Austrheim, 1987; Jolivet et al., 2005). 2) Geochronology can provide absolute ages. Some eclogite-facies minerals have been dated as Scandian (Kylander-Clark et al., 2007; Kylander-Clark et al., 2009), and structures in a rock cut by undeformed in situ melt with, for example, $395 \mathrm{Ma}$ igneous sphene, must be older than $395 \mathrm{Ma}$ (Kylander-Clark et al., 2008). 3) Structures in igneous bodies with Scandian crystallization ages are clearly Scandian or younger (e.g., Hacker et al., 2003a; Lundmark and Corfu, 2008).

\section{Metamorphism of the study area}

All of the WGR has undergone regional metamorphism, however, relict igneous and metamorphic minerals have been preserved over large areas because of coarse grain size, lack of fluids, and/or lack of deformation (Gjelsvik, 1951; Mørk, 1985; Krabbendam et al., 2000). Granulite-facies rocks are found throughout the study area but, except in the Nordfjord area (Bryhni, 1966; Krabbendam et al., 2000; Wain et al., 2001), are too few to warrant discussion in this paper. The eclogite-facies metamorphism (Krogh, 1977; Lappin and Smith, 1978) (Fig. 3) is most easily recognized in the small fraction of mafic rocks scattered throughout the WGR, but is also locally preserved in morefelsic lithologies (Engvik and Andersen, 2000; Wain et al., 2000). The domains of the WGR that contain UHP eclogites are in the western part of the study area ("UHP domains" in Fig. 1). The UHP eclogites record pressures of 3.6-2.7 GPa (Lappin and Smith, 1978); pressures generally diminish southeastward from these domains (Fig. 5), until, at metamorphic pressures of $\sim 1.8-2.0 \mathrm{GPa}$, the eclogites give way to amphibolite-facies parageneses along the dashed line in Fig. 1 (Krogh, 1977; Walsh and Hacker, 2004; Young et al., 2007). The main rocks in the WGR are quartzofeldspathic gneisses that in general do not contain eclogite-facies minerals. Such rocks are not expected to preserve eclogite-facies minerals (Heinrich, 1982), but whether the bulk of the WGR transformed to eclogite-facies minerals (and then backreacted to low-pressure phases) or not has been difficult to assess. High-pressure minerals in WGR quartzofeldspathic rocks are rare and typically confined to the margins of eclogite blocks (Engvik and Andersen, 2000; Wain et al., 2000).

By far the most common metamorphic facies in the study area is amphibolite-facies (Bryhni, 1966; Mysen and Heier, 1971; Labrousse et al., 2002; Terry and Robinson, 2003; Tucker et al., 2004; Walsh and Hacker, 2004; Root et al., 2005). The main quartzofeldspathic gneisses in the study area contain quartz + plagioclase + biotite \pm hornblende \pm garnet \pm K-feldspar. Pelites, which comprise a minor fraction of the WGR, have quartz + plagioclase + muscovite + biotite + garnet \pm kyanite and/or sillimanite; mafic rocks contain plagioclase + hornblende \pm garnet \pm sphene. These mineral assemblages formed chiefly at temperatures of $600-800^{\circ} \mathrm{C}$ and pressures of $1.5-0.5 \mathrm{GPa}-$ conditions characteristic of Barrovian and then Buchan metamorphism (Fig. 3). A general northwestward increase in metamorphic temperature is indicated by calculated temperatures, $\mathrm{U}-\mathrm{Pb}$ sphene ages, the distribution of sillimanite, and textural evidence of in situ partial melting (Fig. 1) (Labrousse et al., 2002; Terry and Robinson, 2003; Tucker et al., 2004; Walsh and Hacker, 2004; Root et al., 2005).

Much of the quartzofeldspathic gneiss in the western half of the study area ('symplectite in' line in Fig. 1) contains fine-grained amphibolite-facies symplectite of biotite + plagioclase (Fig. 6a)

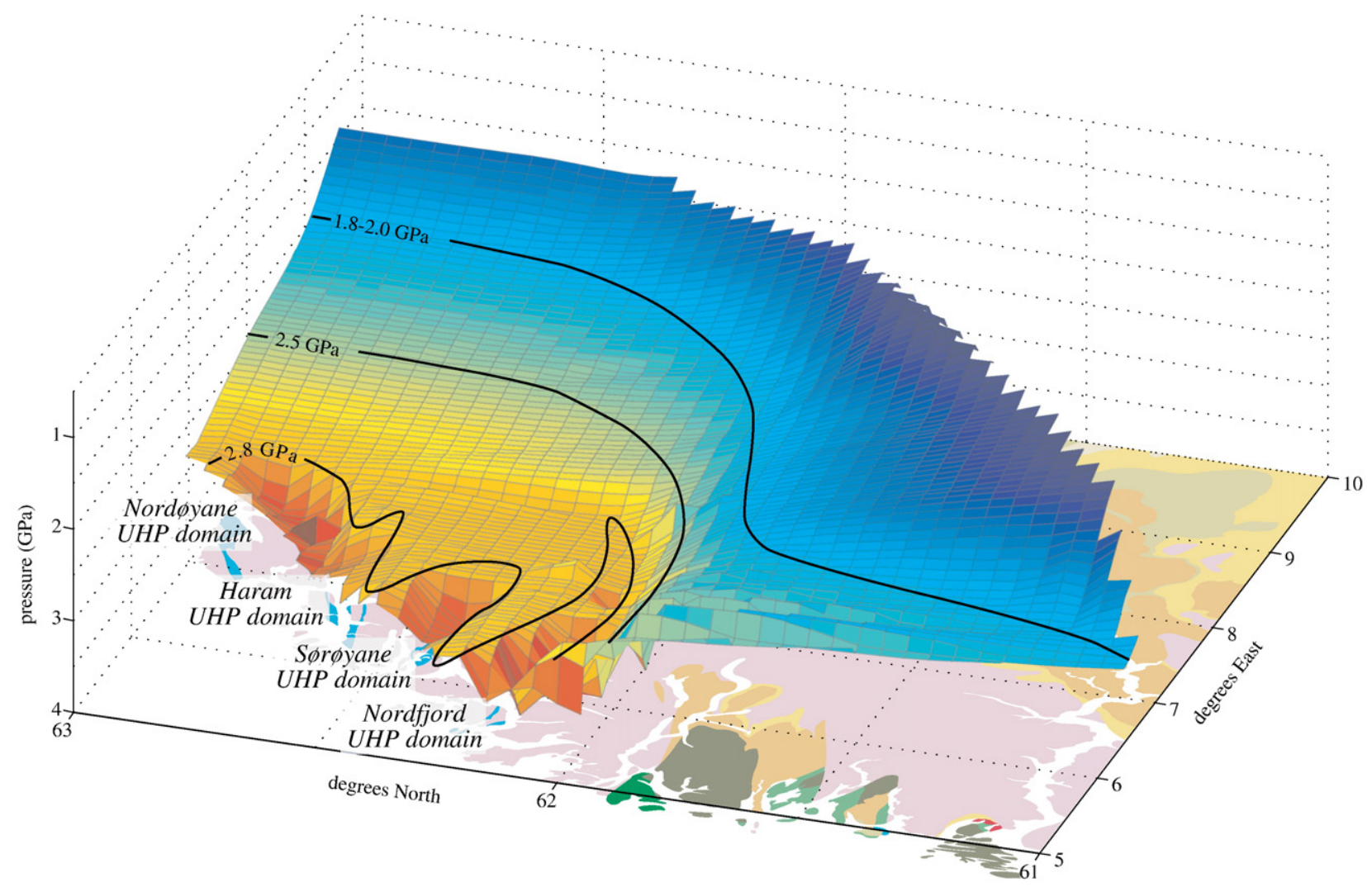

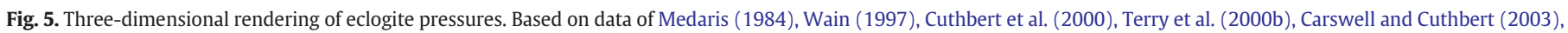
Hacker et al. (2003a), Labrousse et al. (2004), and Ravna and Terry (2004). 

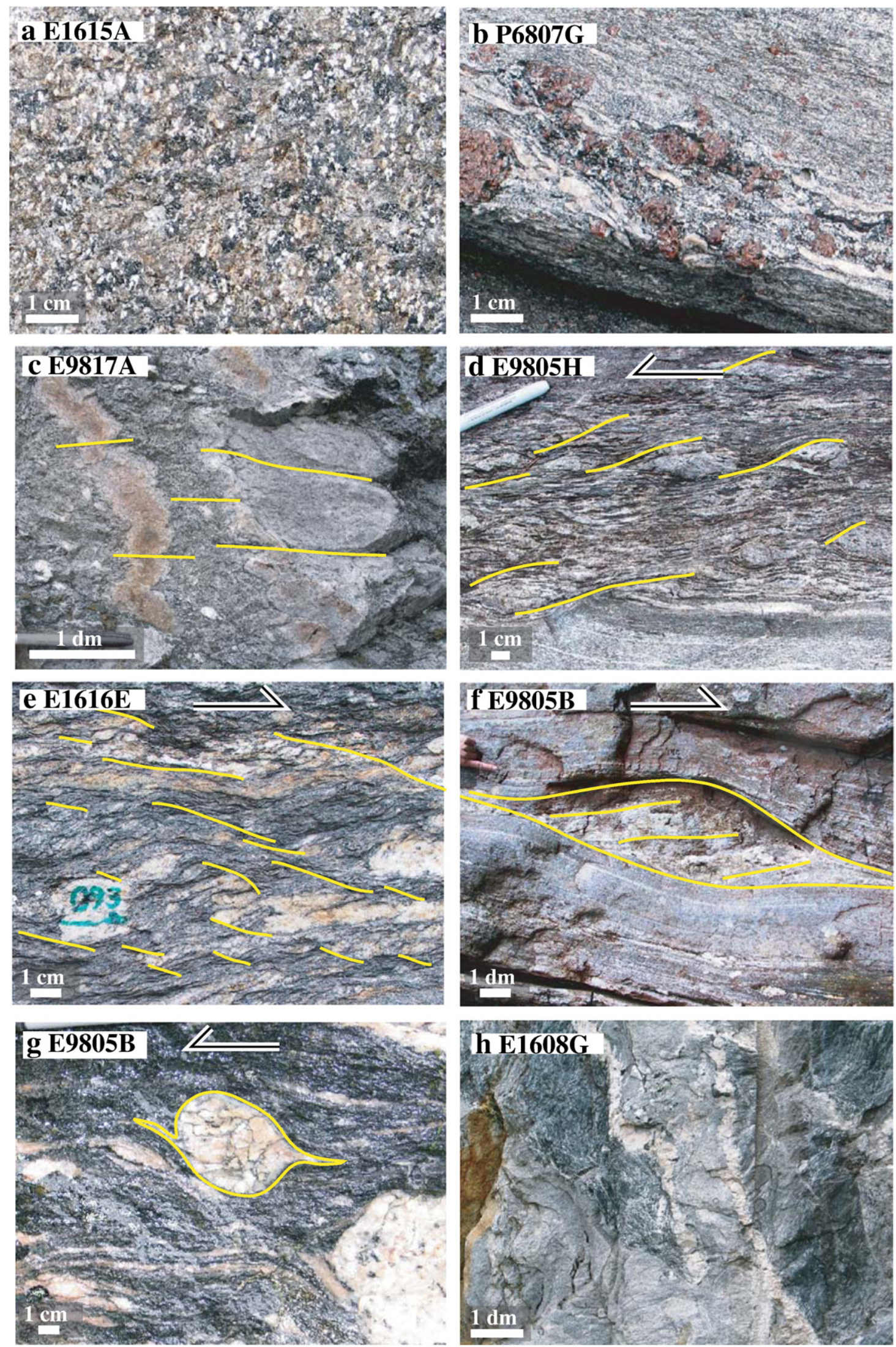

Fig. 6. Outcrop-scale structures; location given in upper left and marked in Fig. 8. a) Early deformation fabric pseudomorphed by symplectite; no subsequent deformation. b) Garnet and plagioclase stable during early amphibolite-facies deformation. c) Minor folds with axial planar biotite cleavage. d) Amphibolite-facies shear bands (looking toward $184^{\circ}$ ). e) Biotite + chlorite stable shear bands (looking toward $003^{\circ}$ ). f) Amphibolite-facies asymmetric boudin (looking toward $050^{\circ}$ ).g) Delta clast within megacrystic K-feldspar augen gneiss (looking toward $245^{\circ}$ ). h) Weakly deformed Precambrian metamorphic fabrics cut by Precambrian intrusions. i) Undeformed granitic segregations formed from in situ melting spatially associated with static hornblende growth. j) Strongly deformed granitic segregations. k) Mylonitic rocks in Stadlandet UHP domain. I) High-strain folds in Sørøyane UHP domain. m) mylonitic rocks in Sørøyane UHP domain. n) Asymmetric boudins and mylonitic gneiss in Nordfjord-Sogn Detachment Zone (looking toward $005^{\circ}$ ). o) Mylonitic K-feldspar augen gneiss in Vågsøy domain. p) Mylonitic foliation in Åmotsdalen domain. 

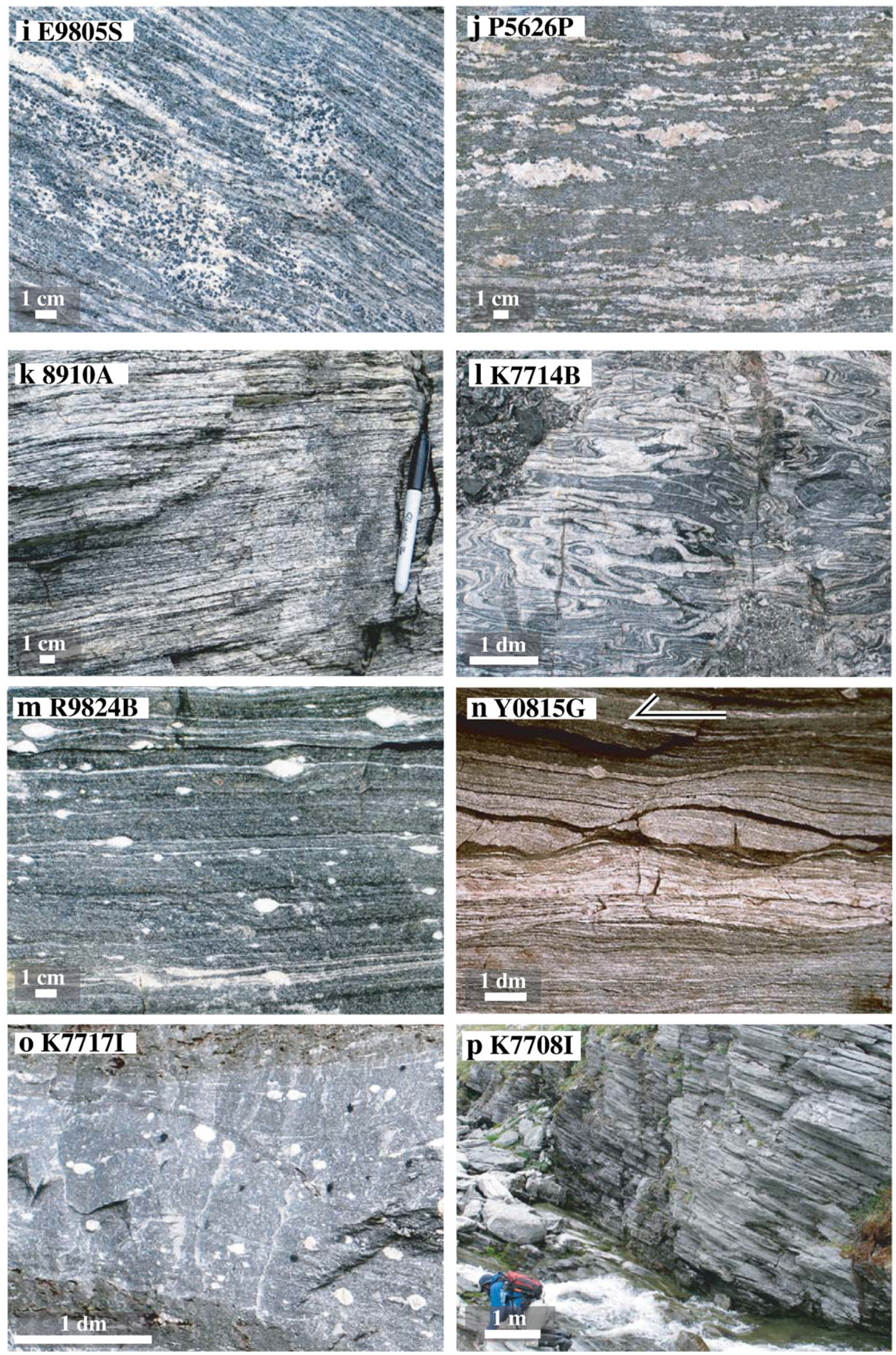

Fig. 6 (continued)

(Dransfield, 1994), whereas the gneiss southeast of the 'symplectite in' line in Fig. 1 has coarse granoblastic textures and no symplectite (Fig. 1). Rocks such as quartzite, biotite schist, and K-feldspar augen gneiss nowhere contain symplectite. Textures in a few outcrops and in many thin sections reveal that the symplectite minerals formed from the decomposition of high-pressure amphibolite-facies K-white mica + 


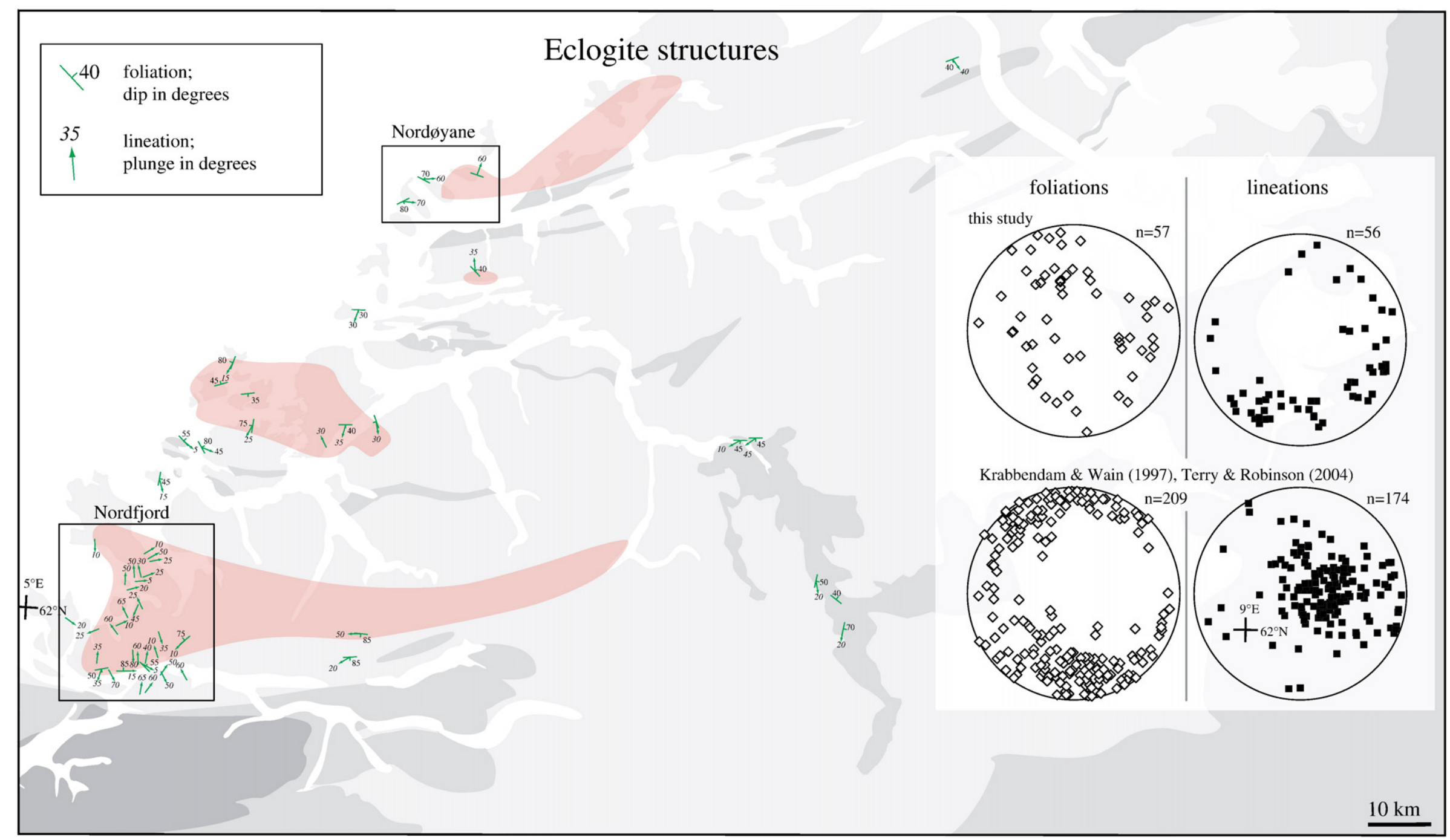

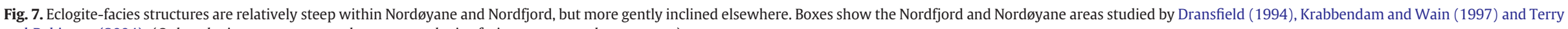
and Robinson (2004). (Only eclogite structures are shown, not eclogite-facies country rock structures.) 


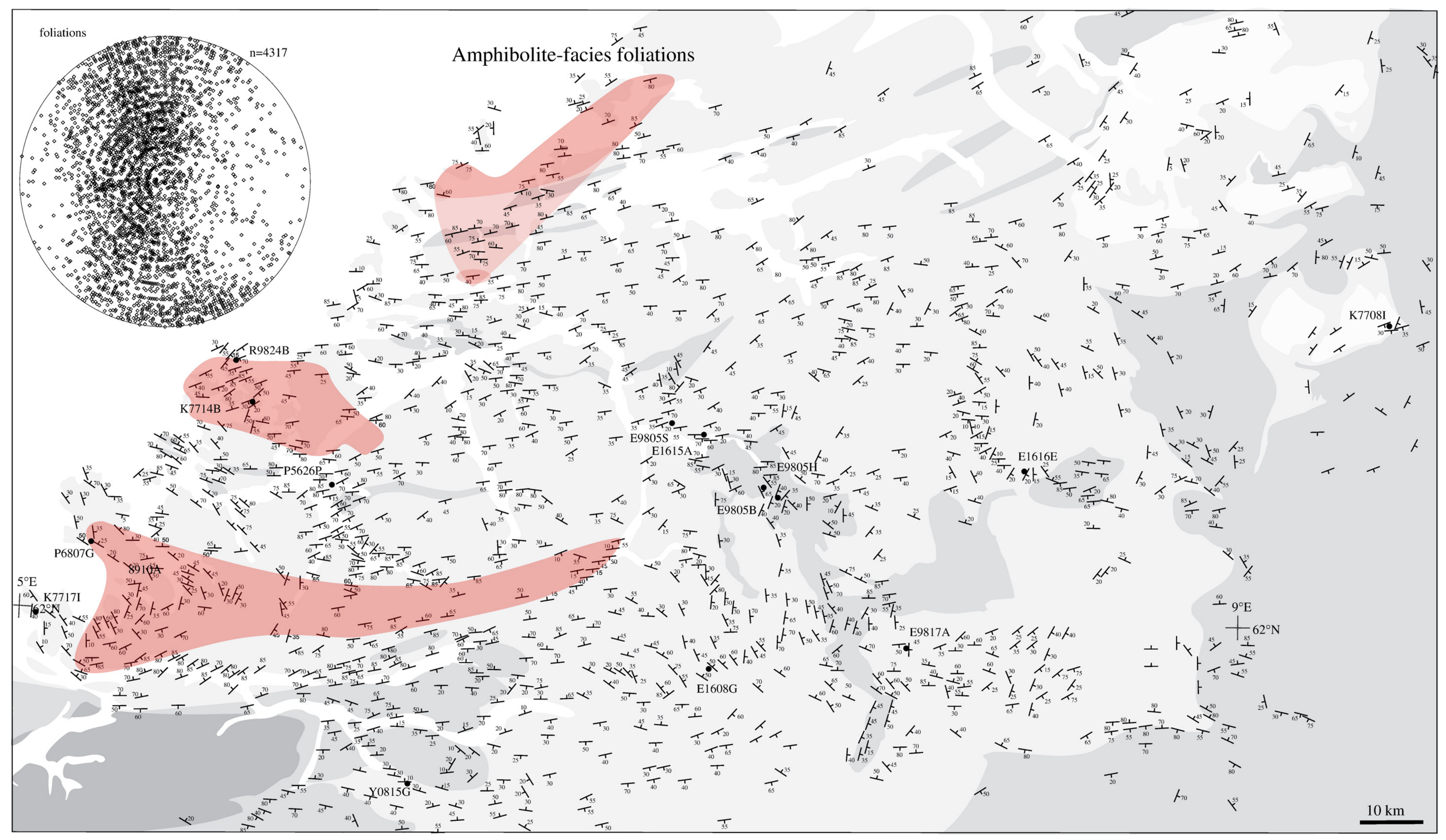

Fig. 8. Amphibolite-facies foliations in the study area are folded about lineation-parallel E-W folds. Some data from Dransfield (1994), Krabbendam and Wain (1997), Lutro and Tveten (1998), Tveten et al. (1998), and Terry and Robinson (2003). Filled circles correspond to locations in Fig. 8. 


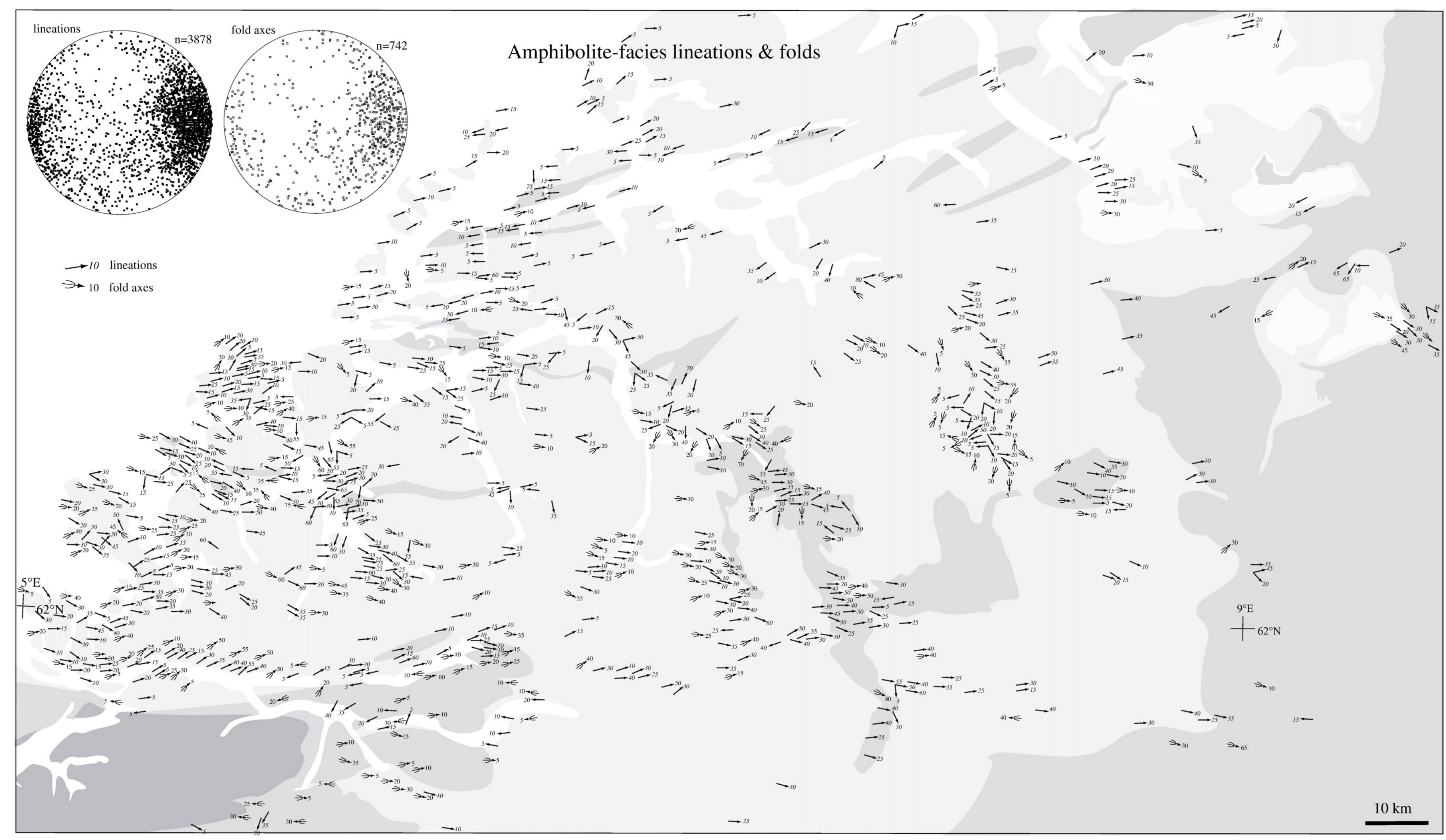

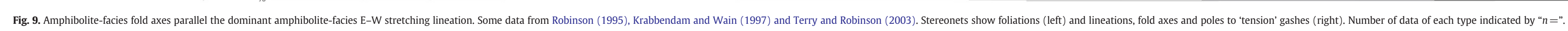


garnet + albite. Pseudosection calculations with Perple_X (Connolly and Petrini, 2002) show that these symplectite-forming reactions occurred during decompression below $\sim 1.0-1.5 \mathrm{GPa}$ and that they conserved or liberated $\mathrm{H}_{2} \mathrm{O}$ (Fig. 3, cf. Heinrich, 1982). Recognition of this symplectite texture, and the interpretation that it formed during decompression, forms a key element in deciphering the Scandian deformation history, because it acts as a strain marker (see below).

\section{Structural geology of the study area}

\subsection{Eclogite-facies structures}

Fabrics in WGR eclogites are defined by garnet, omphacite, orthopyroxene, phengite, kyanite, rutile, quartz, amphibole, zoisite, and/or biotite. Most eclogites are massive, but a modest fraction of them-typically those with hydrous phases (Andersen et al., 1994)are foliated; fewer are lineated. The existing dataset for the Nordfjord (Dransfield, 1994; Krabbendam and Wain, 1997) and Nordøyane (Terry and Robinson, 2004) areas shows mostly steeply plunging lineations on E-W foliation planes (Fig. 7). In contrast, the eclogitefacies structures measured in this study-over a much broader areashow gently plunging lineations on a range of foliation planes. Moreover, all the reported eclogite-facies lineations from the Nordøyane are steep, all those in the Sørøyane are gentle, and those in the Nordfjord area have variable plunge. Steep eclogite-facies lineations are only found along the northwestern edge of the study area; they are gentler farther southeast. In aggregate, these data show that the eclogite-facies structures are relatively steep within Nordøyane and Nordfjord, but more gently inclined elsewhere. Farther south in the WGR a temporal progression from steep N-S to shallow E-W eclogite lineations has been identified (Andersen et al., 1994; Foreman et al., 2005; Engvik et al., 2007).

\subsection{Amphibolite-facies structures}

The amphibolite-facies fabrics are defined principally in quartzofeldspathic gneiss by millimeter- to centimeter-scale K-feldspar, Kwhite mica, hornblende, biotite, plagioclase, quartz, and, locally, kyanite, sillimanite, sphene, and/or garnet. Tension gashes, orthogonal to the local lineation, are filled with these same minerals. In gneiss that underwent partial melting synchronous with the amphibolite-facies deformation, the least-deformed leucosomes define mode-I type 'veins' whose short axes are parallel to the stretching lineation (Austrheim et al., 2003; Labrousse et al., 2004). Outcrop- to thinsection scale textures indicate that, in general, the amphibolite-facies deformation began under conditions where garnet + plagioclase and/ or kyanite were stable and progressed locally to conditions where only plagioclase and/or sillimanite were stable (Fig. 6b).

At the regional scale, the amphibolite-facies structures are typified by E-W striking foliations dipping variably about an E-W axis (Fig. 8), and gently E-W plunging lineations and fold axes (Fig. 9). All these structures show significant domainal variation (Figs. 4 and 10) that is explored below. Boudinage at all scales (Labrousse et al., 2004) led to significant bending of the amphibolite-facies foliations and lineations-as well as more-rarely preserved older structures- around the boudins. Many boudins preserve older(?) amphibolite-facies foliations and lineations that are discordant to those in the surrounding gneiss (see e.g., Dransfield, 1994). Folds are present at all scales. They range from open to isoclinal and typically have lineation-parallel axes; their development produced local rotations of amphibolite-facies lineations by as much as $90^{\circ}$. Together the boudins and folds are responsible for much of the 'scatter' seen in the eclogite-facies and amphibolite-facies foliations and lineations within individual domains (Figs. 7-9). The widespread amphibolite-facies symplectites pseudomorph earlier phases and locally preserve earlier deformation fabrics; the preservation of symplectite indicates an absence of deformation or grain growth because symplectite formation because symplectite is a delicate texture.

These high temperature structures are overprinted locally by a younger, post-symplectite, amphibolite-facies to upper greenschistfacies deformation. The later structures are characterized chiefly by i) biotite mineral lineations developed on pre-existing foliation planes; ii) late folds; and iii) ductile-brittle faults (Braathen, 1999; Walsh et al., in review). The late biotite lineations chiefly plunge E-W at gentle angles (Fig. 11) and are best developed in mica-rich folia within quartzofeldspathic gneiss. The late folds are tight to open, reorient existing folds and lineations, and locally have an axial planar cleavage defined by biotite (Figs. 6c, 11). Most late fold axes plunge gently $\left(10-30^{\circ}\right)$ east or west, and their axial planar cleavage dips gently eastward. These late folds are most evident where the older foliation is steep and cut at a high angle by a gently dipping axial planar cleavage.

Asymmetric fabrics are relatively rare, except in the MøreTrøndelag Fault Complex and the Nordfjord-Sogn Detachment Zone. Their paucity outside those domains is the result of coaxial deformation, low-strain, or overprinting by a retrograde deformation event. It is likely that a dominantly coaxial deformation is the cause, because these are not low-strain rocks and the retrograde overprint was typically static. We measured the orientations and slip directions of amphibolite-facies shear bands (Figs. 6d, e, and 10), asymmetric boudins (Fig. 6f), sigma clasts, and delta clasts (Fig. 6g), where observed. These data, in conjunction with the field observations of Robinson (1995), Terry and Robinson (2003), and Labrousse et al. (2004), and the extensive quartz crystal-preferred-orientation dataset of Barth et al. (2010), show considerable spatial heterogeneity. They collectively indicate mostly top-W/sinistral sense of shear in the western part of the study area and mixed to top-E sense of shear in the east (Figs. 7 and 10). As discussed below, some of the structural domains in the northwest and southeast include large-scale shear zones whose asymmetric structures imply a dominant non-coaxial deformation; most of the domains are, however, not characterized by shear zones, suggesting that the mixed asymmetric indicators within are compatible with domain-scale coaxial deformation. Where the asymmetric fabrics are composed of or overprinted by symplectite or granoblastic (i.e., annealed) amphibolite-facies minerals, we term them "early"; where they postdate symplectite formation or are composed of amphibolite- to greenschist-facies minerals, we term them "late".

\subsection{Structural domains}

Structures in the study area define a number of domains that are characterized by different foliation orientations, lineation orientations, and degree and style of Scandian deformation (Figs. 4, 10, 12; the locations of the cross sections in Fig. 12 are shown in Fig. 10). The domains also show variations in eclogite age, garnet age, sphene age, and muscovite age. The eclogite ages indicate the time of eclogite-facies recrystallization (see summary in Kylander-Clark et al., 2009), the sphene ages mark either neocrystallization in melt or Scandian Pb loss (Tucker et al., 2004; Kylander-Clark et al., 2008), and the muscovite ages reflect cooling through $\sim 400{ }^{\circ} \mathrm{C}$ (Hacker, 2007; Walsh et al., in review). (Citations for the many ages cited in this section can be found in these last five references.) To make the link between the domainal data and the interpretation of the entire study area clearest, the description of each domain ends with an interpretation.

The Reinheimen domain consists chiefly of a gently E-dipping homocline with a modestly E-plunging lineation and folds (best-fit lineation is 081/29; Fig. 4). Typical are coarse-grained rocks that have only a weak lineation (Fig. 6 h), lack symplectite, and have minor in situ 'melt' pockets (i.e., leucocratic, typically granitic, segregations) that cut the foliation, are undeformed and are spatially associated with static hornblende and/or plagioclase blasthesis (Fig. 6i). Asymmetric structures are rare-implying bulk coaxial deformation-but the few data 


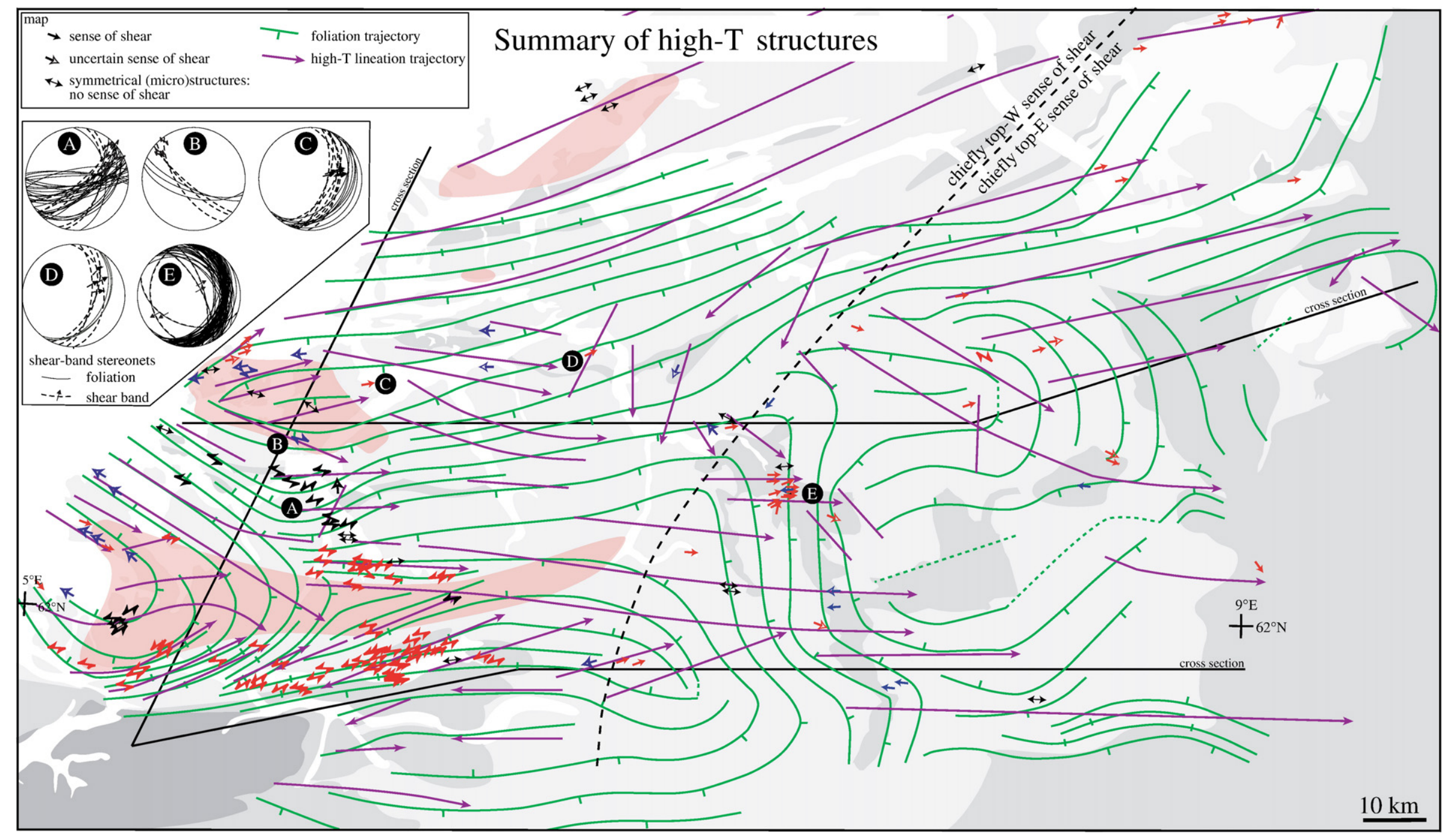

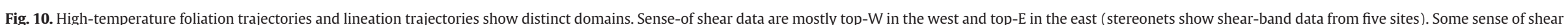

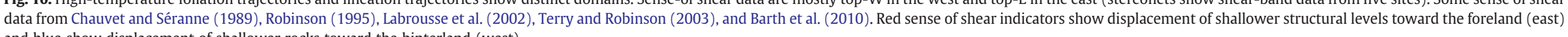
and blue show displacement of shallower rocks toward the hinterland (west) 


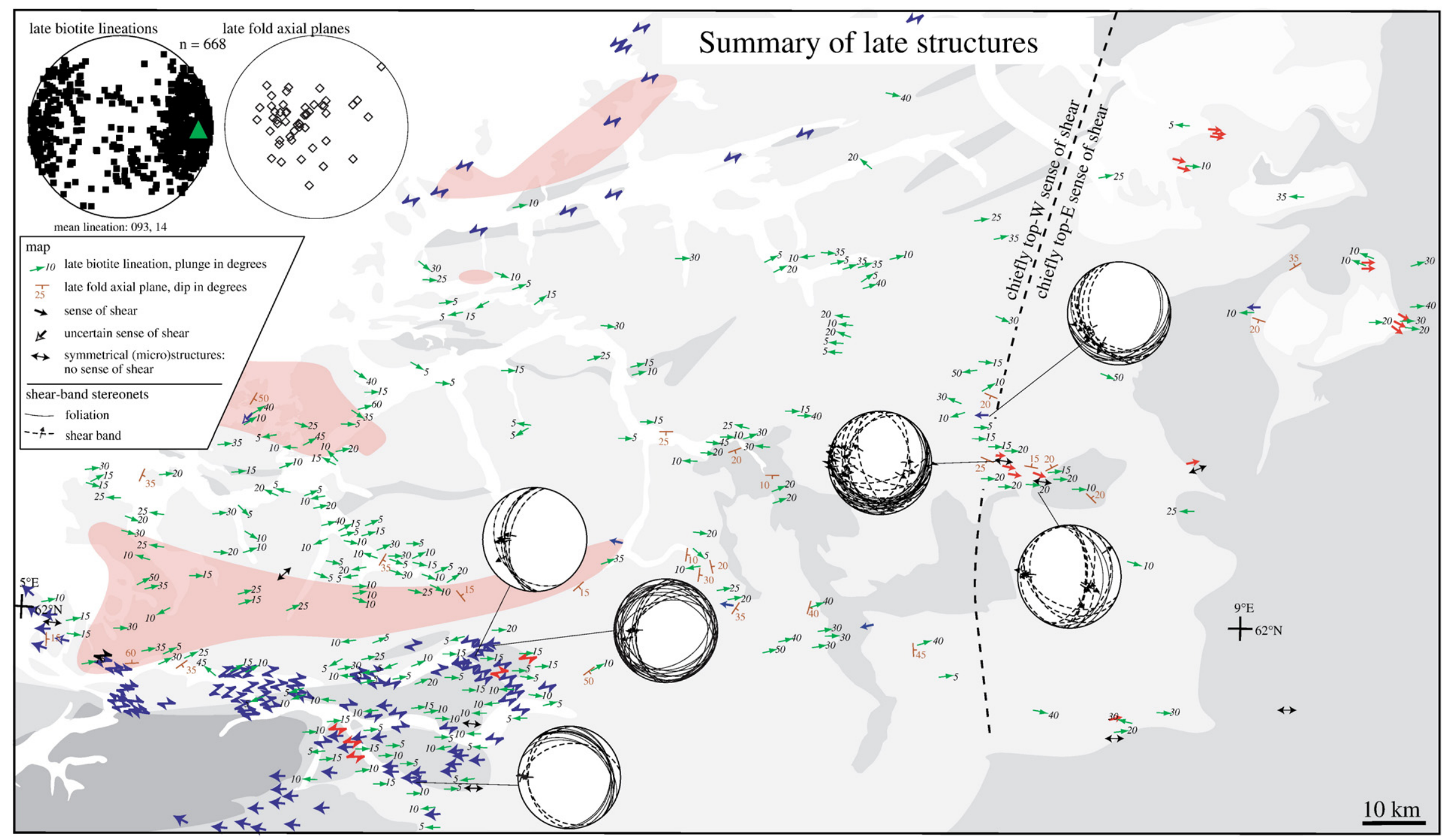

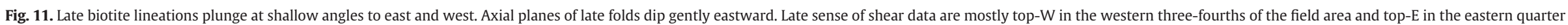
(stereonets show shear-band data from six sites). Some data from Chauvet and Séranne (1989), Robinson (1995), Labrousse et al. (2002), and Barth et al. (2010). 


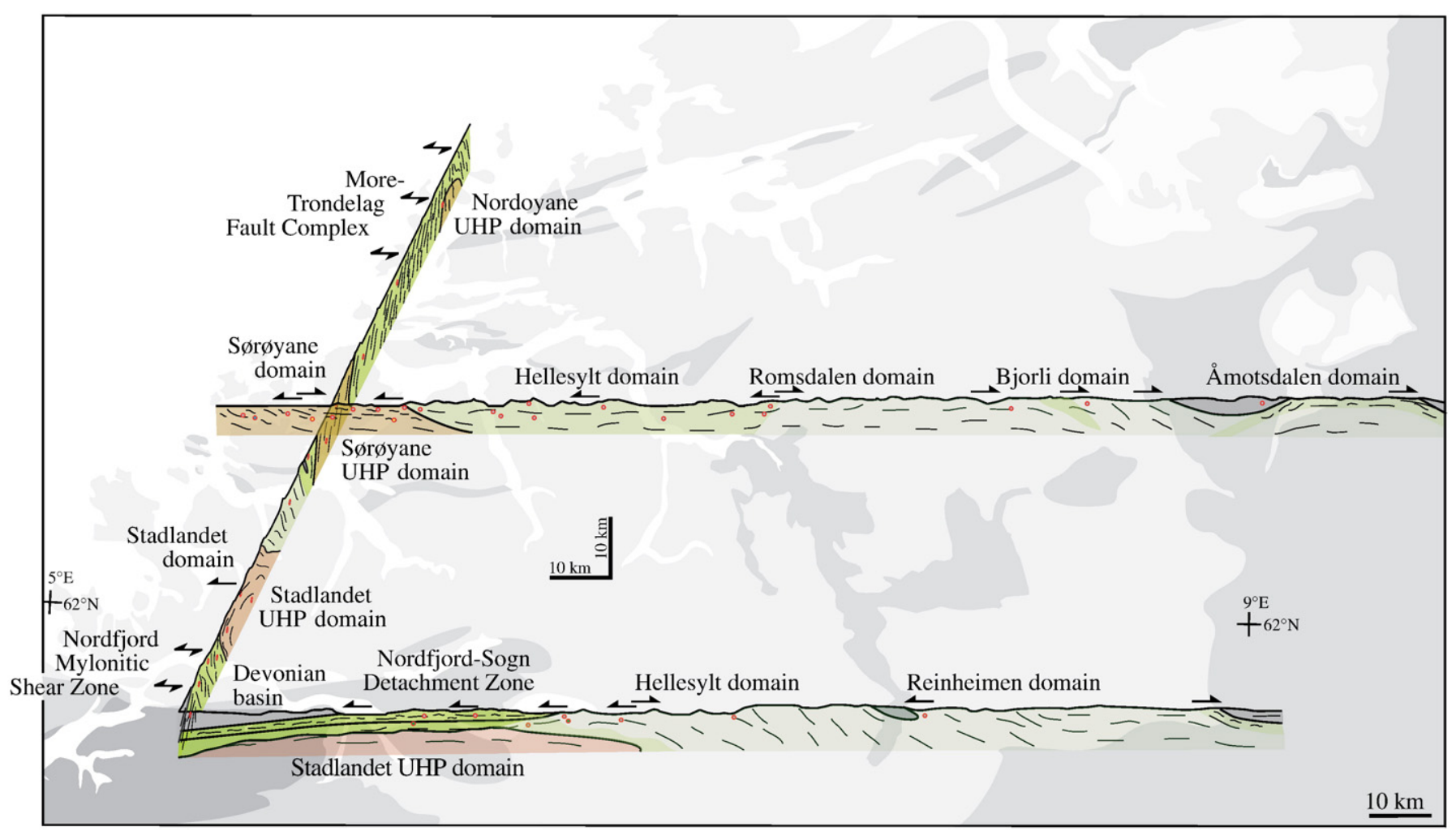

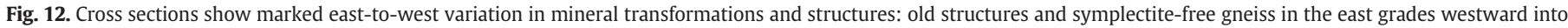
young structures and symplectite-bearing gneiss in the west. Arrows show sense of shear. Use of colors follows Fig. 1.

indicate early, mostly top-E sense of shear (Fig. 10). If the allochthons shown in Fig. 1 were emplaced in the Scandian, some of this deformation is Scandian. Late Scandian deformation consists of slip along biotite-rich foliation planes and local folds with axial planar cleavage composed of biotite (Fig. 11). Zircons from weakly deformed granodiorites and granitic pegmatites that cut earlier strong fabrics are c. $950 \mathrm{Ma}$ (Tucker et al., 1990). Two sphenes from a single gneiss outcrop gave partially reset Precambrian ages, whereas white-mica ages are 399393 Ma. Interpretation: The main structures are likely a mix of Precambrian and early Scandian deformation; the late Scandian orogeny produced chiefly static recrystallization and minor localized slip.

The Romsdalen domain has a mostly gently S-dipping foliation. Typical are fine-grained rocks formed of symplectite that overprints an earlier, now weak lineation, and minor in situ 'melts' that cut the foliation, are undeformed and are spatially associated with static hornblende and/or plagioclase blasthesis. Most measured lineations plunge gently $\left(9^{\circ}\right)$ eastward, but a significant subset is steep. Moreover, a significant number of widely dispersed outcrops have S-trending lineations of variable plunge; the E- and S-trending lineations are defined by the same minerals: quartz, K-feldspar, plagioclase, muscovite, hornblende, and garnet. Asymmetric structures are rare, implying coaxial deformation, but the few data indicate early, mostly top-E sense of shear; one late sense of shear indicator is top-W. Late deformation produced slip along biotite-rich foliation planes and local folds with axial planar cleavage composed of biotite, but much of the gneiss was not deformed after symplectite growth. Four sphene samples in this domain define a transition from Precambrian to Scandian U-Pb ages; one from a syntectonic 'melt' segregation is $398 \mathrm{Ma}$ whereas one from a post-tectonic 'melt' segregation is $777 \mathrm{Ma} .{ }^{40} \mathrm{Ar} /{ }^{39} \mathrm{Ar}$ muscovite ages are 394-391 Ma. Interpretation: Like the Reinheimen domain, the main deformation is likely Precambrian and early Scandian; the Scandian orogeny produced chiefly static recrystallization through $398 \mathrm{Ma}$ and minor localized slip afterward.
The Bjorli domain is similar to the Reinheimen domain in that it consists mostly of E-dipping foliation planes. It differs, however in being characterized by chiefly pre-symplectite, amphibolitefacies deformation of moderate intensity with a subhorizontal $\left(1^{\circ}\right)$ E-plunging lineation; it has gently $\mathrm{N}-\mathrm{S}$ plunging folds and abundant, post-symplectite asymmetric structures with mixed top-W and top-E sense of shear indicated by porphyroclasts, folds, and shear bands formed during amphibolite-facies to greenschist-facies conditions (Figs. 6e, 11). It is effectively a late shear zone within the Romsdalen and Reinheimen domains; the northern and southern extents of this zone are unknown. The amphibolite-facies and greenschist-facies deformations in this domain likely predate and postdate, respectively, nearby muscovite ${ }^{40} \mathrm{Ar} /{ }^{39} \mathrm{Ar}$ ages of $~ 399 \mathrm{Ma}$ to $393 \mathrm{Ma}$. Interpretation: The deformation that defines this zone is late Scandian amphibolitefacies to greenschist-facies E-W extension.

The Hellesylt domain is the southeasternmost domain with evidence of UHP metamorphism. It includes E-W striking foliation with variable-but chiefly steep-dips and gently $\left(18^{\circ}\right)$ E-plunging lineation. Typical are fine-grained rocks formed of symplectite that overprints an earlier, now weak to modest lineation, and minor amounts of in situ 'melts' that are weakly to moderately deformed; the amount of melt increases northward. The fabrics are almost entirely symmetrical, implying coaxial deformation; there is only one late, top-W indicator. Late deformation produced slip along biotiterich foliation planes and local folds with axial planar cleavage composed of biotite, but much of the gneiss was not deformed after symplectite growth. One eclogite from the Hellesylt domain gave a Sm-Nd age of $398.3 \pm 8.1 \mathrm{Ma}$, and muscovite ${ }^{40} \mathrm{Ar} /{ }^{39} \mathrm{Ar}$ ages are 390 386 Ma. Three sphenes from syntectonic leucosomes range from $398 \mathrm{Ma}$ to $391 \mathrm{Ma}$. Interpretation: The main deformation continued through at least $398 \mathrm{Ma}$, was followed by symplectite growth after $391 \mathrm{Ma}$ and then minor amphibolite-facies deformation occurred in discrete zones prior to 390 Ma. 
The Åndalsnes domain includes a moderately SSE-dipping homocline with a gentle $\left(15^{\circ}\right)$ ENE-WSW plunging lineation. Typical are fine-grained rocks formed of symplectite that overprints an earlier, weak to modest lineation, and minor amounts of in situ 'melts' that are moderately deformed. Asymmetric structures are rare, implying coaxial deformation, but the few data indicate early, mostly top-E sense of shear. Late slip occurred along biotite-rich foliation planes, but much of the gneiss was not deformed after symplectite growth. Five sphene samples in this domain define a transition from Precambrian to Scandian U-Pb ages; muscovite ${ }^{40} \mathrm{Ar} /{ }^{39} \mathrm{Ar}$ ages are 404-388 Ma. Interpretation: The main amphibolite-facies deformation was followed by symplectite growth and then minor amphibolitefacies deformation in discrete zones prior to 404-388 Ma.

The Stranda and Volda domains share aspects of the adjacent Romsdalen, Åndalsnes and Hellesylt domains, but include particularly high concentrations of S-plunging lineations in addition to the usual gently E-plunging lineations. Interpretation: The age and kinematic relations between the $\mathrm{S}$ - and $\mathrm{E}$-plunging lineations are undocumented.

The Stadlandet domain defines a gently $\left(22^{\circ}\right)$ ESE-plunging fold with NNE-dipping limbs cored by UHP rocks (Krabbendam and Wain, 1997; Labrousse et al., 2004). Typical are medium-grained rocks formed of coarsened symplectite that overprints an earlier, moderate to strong lineation that plunges gently to moderately eastward. In situ 'melts' that are moderately to strongly deformed increase in abundance northwestward (Fig. 6j); some quartz CPOs show prism-[c] slip (Barth et al., 2010), typical of granulite-facies temperatures (Lister and Dornsiepen, 1982). Significant zones of mylonitic gneiss and mylonite are present (Fig. 6k)-some with abundant asymmetric structures-but these have not been extensively studied. Asymmetric structures show early mixed top-W and top-E sense of shear, implying bulk coaxial deformation. Late deformation produced slip along biotite-rich foliation planes, but much of the gneiss was not deformed after symplectite growth. The dated eclogites in this domain range from 420-400 Ma, and muscovite ${ }^{40} \mathrm{Ar} /{ }^{39} \mathrm{Ar}$ ages fill the range $392-$ $374 \mathrm{Ma}$. Sphenes show a mix of Precambrian and Scandian U-Pb ages, and the youngest, $390 \mathrm{Ma}$, comes from a syntectonic leucosome. Interpretation: The main deformation-chiefly coaxial, but including mylonitic zones-continued through at least $390 \mathrm{Ma}$, was followed by symplectite growth and then minor amphibolite-facies deformation occurred in discrete zones prior to 392-374 Ma.

The Sørøyane domain is a gently S-dipping homocline that contains UHP and HP rocks (Root et al., 2005). Typical are mediumgrained rocks formed of coarsened symplectite that overprints an earlier, moderate to strong, subhorizontal $\left(7^{\circ}\right)$ ENE-plunging lineation. Moderately to strongly deformed in situ 'melts' are abundant, such that there are local areas in which rootless folds are 'floating' in melt (Fig. 6l); some quartz CPOs show prism-[c] slip (Barth et al., 2010). Significant zones of mylonitic gneiss and mylonite are present (Fig. $6 \mathrm{~m}$ ), but these have not been extensively studied. Some of them postdate symplectite formation, but much of the gneiss was not deformed after symplectite growth. Asymmetric structures show early mixed top-W and top-E sense of shear, implying coaxial deformation at the domain-scale. The dated eclogites in this domain are all $\sim 400 \mathrm{Ma}$, the sphenes from syntectonic leucosomes have $\mathrm{U}-\mathrm{Pb}$ ages of mostly 391-389 Ma, and the white micas are 389-380 Ma. Interpretation: The main deformation-chiefly coaxial, but including mylonitic zones-continued through at least $400 \mathrm{Ma}$, was followed by symplectite growth and then minor amphibolite-facies deformation in discrete zones prior to $389 \mathrm{Ma}$.

The Møre-Trøndelag Fault Complex (MTFC) domain (Grønlie and Roberts, 1989) is unusual in two ways. It contains the largest known zone of eclogite-facies structures (on Flemsøya, Fjørtoft, and Haramsøya), which are dominantly steep and interpreted to represent back-rotated, originally gently inclined and top-SE structures (Terry and Robinson, 2004). These are overprinted by amphibolite-facies structures that are almost exclusively steeply dipping, ENE-WSW striking foliations with subhorizontal $\left(7^{\circ}\right)$ ENE-plunging lineations (Séranne, 1992; Robinson, 1995; Terry and Robinson, 2003; Tucker et al., 2004); it locally contains UHP rocks (Dobrzhinetskaya et al., 1995; Terry et al., 2000b; Vrijmoed et al., 2006). This lineation orientation is different than the E-trending lineations of nearby domains, and overprinting relationships suggest that it is part of a progressive change from E-W to ENE-WSW stretching (Terry and Robinson, 2003). Typical are medium-grained rocks formed of coarsened symplectite that overprints an earlier strong lineation; in situ melts range from weakly to strongly deformed. Significant zones of mylonitic gneiss and mylonite are present; some of these postdate symplectite formation and have ductile-brittle feldspar, suggesting lower amphibolite-facies deformation. Asymmetric structures are abundant inside and outside the high-strain zones and indicate early and late sinistral shear. Nearly all the dated eclogites in this domain are $415-410 \mathrm{Ma}$, monazite is $398 \mathrm{Ma}$ (Terry et al., 2000a), sphene from a syntectonic leucosome is $393 \mathrm{Ma}$, and white micas are 388$370 \mathrm{Ma}$. Interpretation: The main sinistral deformation was ongoing at $393 \mathrm{Ma}$, was followed by symplectite growth, and then continued in discrete zones prior to 388-370 Ma.

The Nordfjord Mylonitic Shear Zone (NMSZ) domain (Labrousse et al., 2004) is similar to the MTFC in that it consists of steeply dipping, ENE-WSW striking foliation and gently $\left(17^{\circ}\right)$ ENE-plunging lineation. Typical are medium-grained rocks formed of coarsened symplectite that overprints an earlier strong lineation; some quartz CPOs show prism-[c] slip (Barth et al., 2010). Asymmetric structures are abundant and show both sinistral and dextral shear. The sinistral structures are older than the dextral structures, Labrousse et al. (2004); the latter are related to slip on the Nordfjord-Sogn Detachment Zone (Krabbendam and Wain, 1997), whereas the former predate the NSDZ. Significant zones of mylonitic gneiss are present and may continue 10's of kilometers farther east than shown in Fig. 4. In contrast to the MTFC, in situ melts are rare. One eclogite gave a zircon age of $405 \pm 2 \mathrm{Ma}$; muscovite ${ }^{40} \mathrm{Ar} /{ }^{39} \mathrm{Ar}$ ages are $399-388 \mathrm{Ma}$. Interpretation: The main sinistral deformation was ongoing after $405 \mathrm{Ma}$, was followed by symplectite growth, and then continued in discrete zones prior to 399-388 Ma.

The Nordfjord-Sogn Detachment Zone (NSDZ) is unique in that it is dominated by mylonitic gneiss and mylonite with generally flatlying foliation and subhorizontal ( $6^{\circ}$ plunge eastward) lineation (Norton, 1987; Andersen and Jamtveit, 1990; Fossen, 1992; Andersen et al., 1994; Dransfield, 1994; Krabbendam and Wain, 1997; Andersen, 1998; Johnston et al., 2007a; Young et al., 2007). These fabrics are developed mostly in allochthonous rocks, but extend up to $5 \mathrm{~km}$ structurally downward into the WGC basement. Typical are mediumgrained to very-fine-grained rocks with abundant asymmetric structures that indicate near-universal top-W shear (Fig. 6n). No in situ melt has been noted. Deformation began under amphibolitefacies conditions at depths of 30-40 km between 410 and $400 \mathrm{Ma}$ (Johnston et al., 2007b); deformation continued during cooling, such that the lower amphibolite-facies to greenschist-facies deformation chiefly postdated symplectite formation. Muscovite in the NSDZ ages are 392-388 Ma. The Vågsøy domain structures are identical to those in the NSDZ (Fig. 6o); the two domains are separated at the surface by the Hornelen Fault, but are presumably contiguous in the subsurface. Interpretation: The main top-W extensional deformation occurred at crustal levels from 410-400 Ma to 392-388 Ma.

The Vågåmo domain consists of a narrow strip of the WGC and adjacent allochthons that define a steeply dipping, E-W striking foliation and moderately $\left(28^{\circ}\right)$ E-plunging lineation. Scandian deformation is moderate and characterized by local mylonitic fabric. The sense of shear is poorly known: two measurements indicate coaxial shear. No eclogites are known from this domain, there is no symplectite, and there are no Scandian in situ melts. One sphene from a garnetbearing gneiss gave a Precambrian $\mathrm{U}-\mathrm{Pb}$ age, and nearby muscovite ${ }^{40} \mathrm{Ar} /{ }^{39} \mathrm{Ar}$ ages are 398 and $393 \mathrm{Ma}$. Interpretation: Deformation along 
a) $435-415 \mathrm{Ma}$ : emplacement of allochthons, continental collision

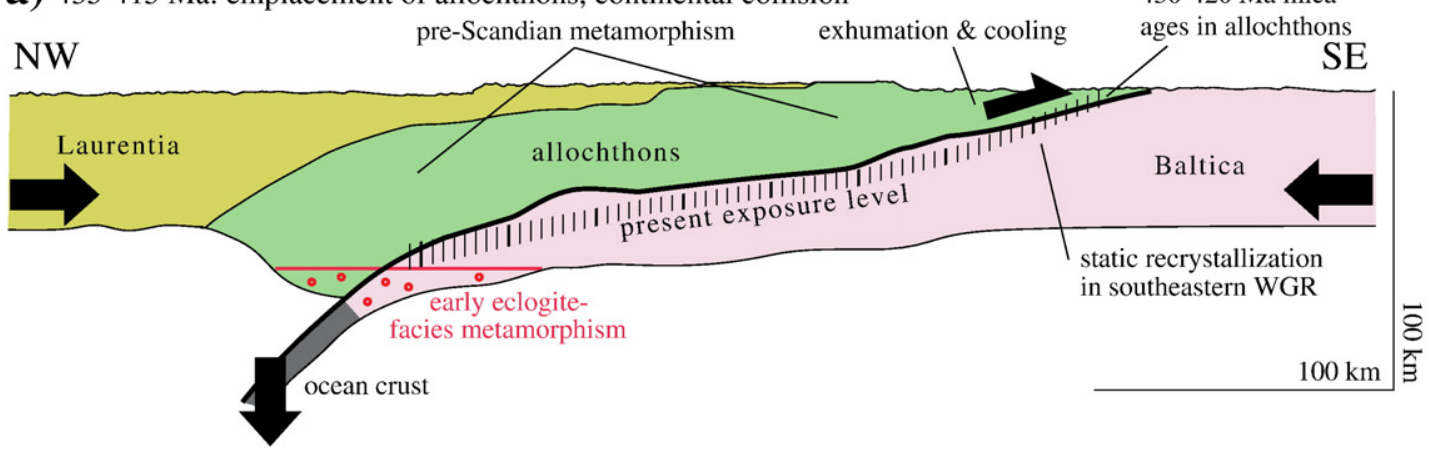

b) 415-400 Ma: continental subduction

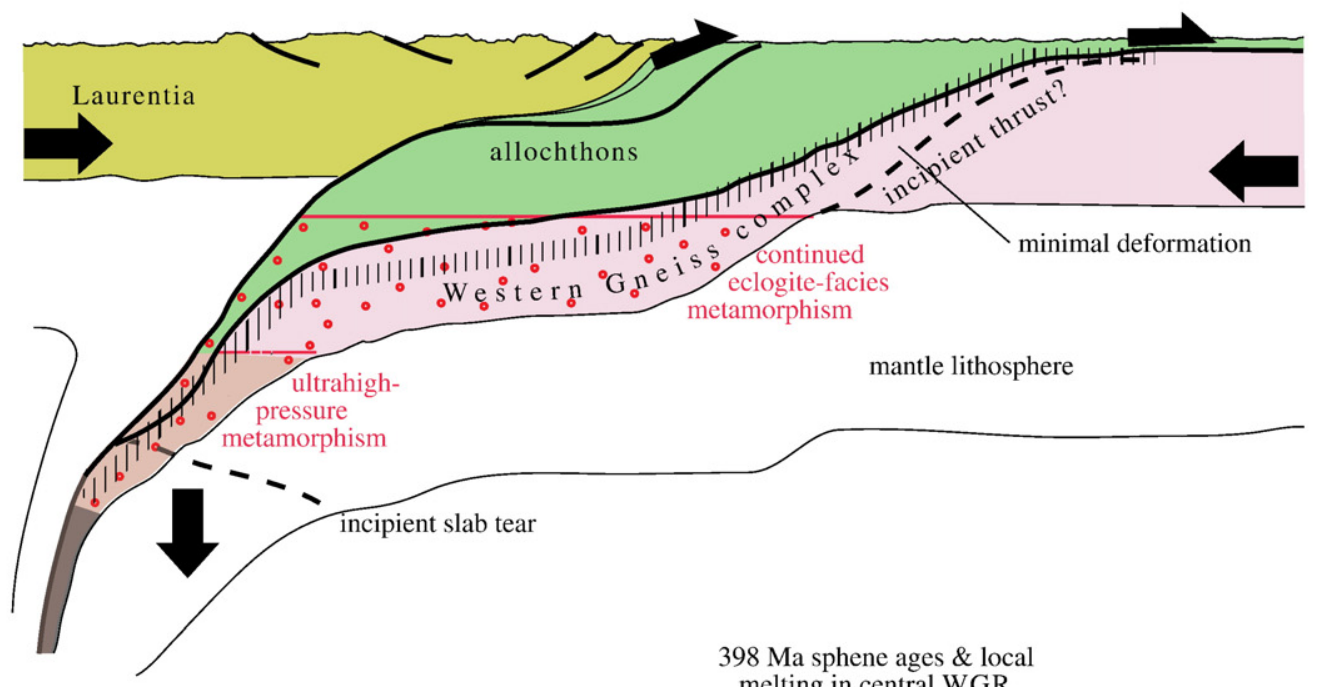

c) 400-395 Ma: progressive E-to-W exhumation melting in central WGR

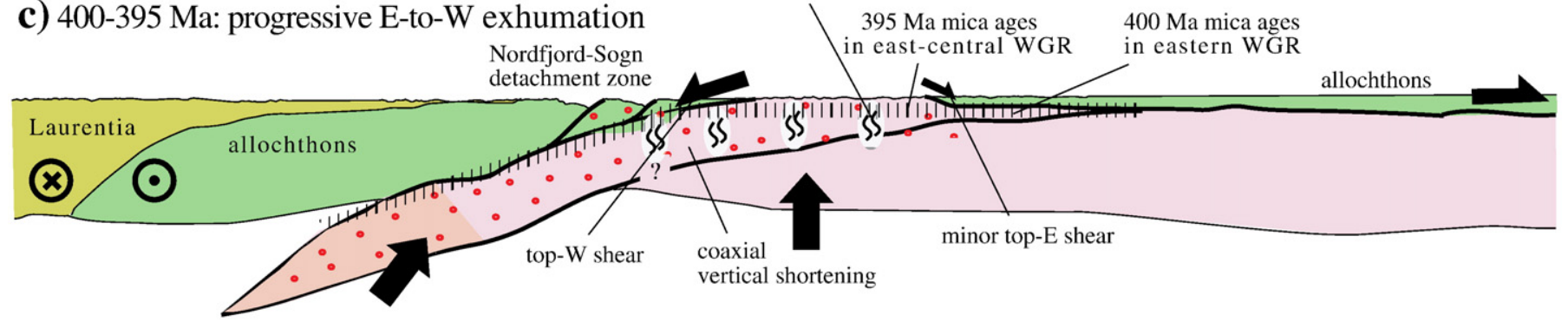

d) 395-385 Ma: progressive E-to-W exhumation 390 Ma mica ages

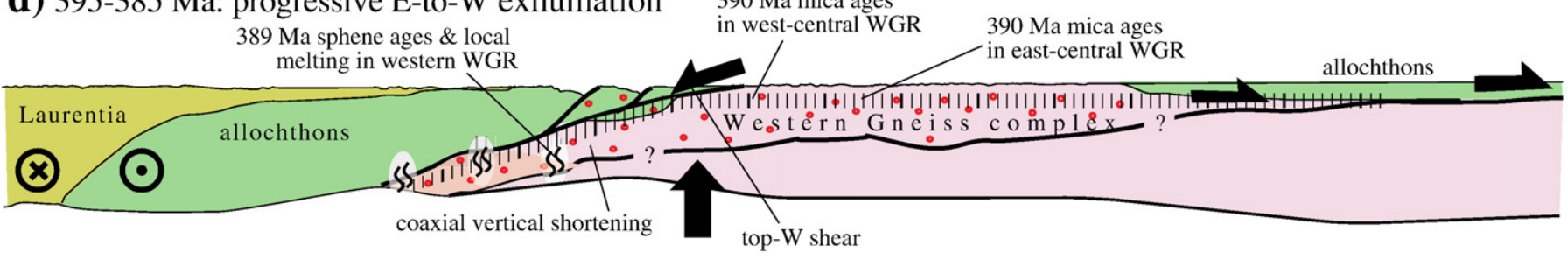

e) <380 Ma: exhumation of UHP NW by late folding in western WGR

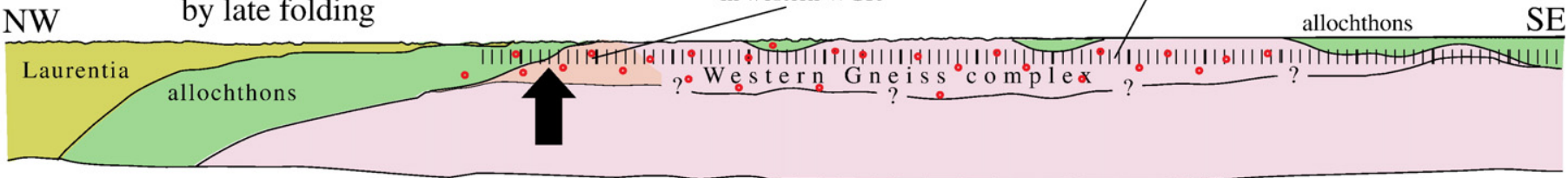


the WGC-allochthons contact occurred during the Scandian prior to 398 Ma.

The Åmotsdalen domain consists of a narrow strip of the easternmost WGC and overlying allochthons; most of our observations are from the WGC. No eclogites are known from this domain, there is no symplectite, and there are no Scandian in situ melts. The rocks have a gently E-dipping foliation and $\left(14^{\circ}\right)$ E-plunging lineation. Moderate Scandian deformation is indicated by the presence of significant mylonitic to phyllonitic zones (Fig. 6p); ductile-brittle feldspar, ductile quartz and "mixed-<a>slip" quartz CPOs (Barth et al., 2010) suggest lower amphibolite- to upper greenschist-facies deformation. Sense-of shear indicators from outcrops and CPOs show chiefly top-E motion (Fig. 11). Because the deformation occurred at temperatures similar to Ar closure in muscovite, and nearby muscovite ${ }^{40} \mathrm{Ar} /{ }^{39} \mathrm{Ar}$ ages are $403 \mathrm{Ma}$ to $399 \mathrm{Ma}$, the deformation may be of a similar age. South of the study area, the WGC-allochthon contact developed as a thrust through $\sim 410 \mathrm{Ma}$, and then was overprinted and modified by top-NW extension (Fossen, 1992; Andersen, 1998; Fossen, 2000). Interpretation: Scandian top-E deformation-likely around 403-399 Maoccurred along the WGC-allochthons contact.

In summary, early structures are preserved in the southeastern half of the study area, chiefly in the Reinheimen and Romsdalen domains (and to a lesser extent in the Åndalsnes, Åmotsdalen and Vågåmo domains). Sphene from cross-cutting leucosomes and zircon from crosscutting intrusions demonstrate that some of this deformation is Precambrian, and yet the presence of what are inferred to be allochthons emplaced in the Caledonian implies local significant Scandian deformation. Deformation clearly recognizable as Scandian is limited to a weak reworking of these structures. The Scandian reworking becomes progressively stronger westward, culminating in the northwest in strong Scandian fabrics with only isolated pockets of Precambrian structures; this is similar to the structure inferred for the Sognefjord transect $100 \mathrm{~km}$ farther south by Milnes et al. (1997). This dominant Scandian deformation was coaxial at the outcrop scale, with local top-W and top-E shear zones that may approximate large-scale coaxial deformation. The bulk of the study area (the Stadlandet, Volda, Hellesylt, Stranda, Åndalsnes, Romsdalen, Reinheimen and Vågåmo domains) can be described crudely as an E-dipping homocline with $15-29^{\circ} \mathrm{E}$-plunging lineations that exposes deeper, more strongly deformed, more eclogiterich structural levels westward. In the western half of the study area, however, the foliations are in general flat lying or folded about E-W axes. This homocline-like feature is bounded north and south by the sinistrally sheared Møre-Trøndelag Fault Complex and the Nordfjord Mylonitic Shear Zone. The S-plunging lineations that are preserved locally (chiefly in the Volda, Stranda, and Romsdalen domains) would trend southeastward if the homoclinal section is rotated back to horizontal. Scandian partial melts are absent in the south and progressively more prevalent toward the north(west). In the southeast, the partial melts are undeformed and associated with static mineral growth; in the northwest, they are strongly deformed and range from 398 in the center of the study area to $389 \mathrm{Ma}$ in the west. In most domains, the bulk of the Scandian deformation was followed by decompression-related symplectite formation in the main quartzofeldspathic gneiss, and further deformation was restricted to slip along biotite-rich foliation planes and minor local folding. The edges of the study area, however, continued to undergo further deformation during decompression and cooling: 1) The Åmotsdalen, Bjorli, and Vågåmo domains underwent modest amphibolite-facies deformation with top-E shearing, likely related to continued translation of the allochthons over the basement. 2) The Møre-Trøndelag Fault Complex underwent further strong amphibolite-facies sinistral shear in localized mylonitic domains. 3) The Stadlandet and Sørøyane domains experienced local additional strong amphibolite-facies mylonitization. 4) The NordfjordSogn Detachment Zone underwent strong lower amphibolite-facies to greenschist-facies top-W shearing.

\section{Discussion}

How do the data presented above bear on questions raised in the Introduction regarding i) the temporal variations in deformation, ii) the relationship between metamorphism and deformation, iii) the size and coherence of UHP terranes, and iv) the style and intensity of deformation of UHP terranes during subduction and exhumation?

\subsection{Summary of Scandian tectonism in the study area}

Previous research and observations reported herein permit the following history for the study area during the Scandian orogeny; other parts of the WGR experienced or recorded different histories. From 435-415 Ma, allochthons were emplaced (south)eastward onto the WGC contemporaneous with the last stages of continentalmargin sedimentation (Andersen et al., 1990). This was associated in the allochthons east of the study area with pre- to early Scandian metamorphism and exhumation that produced closure of micas to $\mathrm{Ar}$ loss (e.g., Hacker and Gans, 2005) (Fig. 13a). Subsequently, the WGR and portions of the overlying allochthons began to be subducted, reaching HP conditions. Deformation related to this process progressed across the WGR, leaving a record in partially overprinted older structures in the Reinheimen, Romsdalen, and Åndalsnes domains (Fig. 10), in the top-E fabrics in the Åmotsdalen domain, and in the top-E prism-[c] quartz CPOs in the Sørøyane and Stadlandet domains (Barth et al., 2010). The emplacement direction may have been southerly or southeastward for part of the time-based on the local preservation of S- and SE-plunging lineations in the study areaas has been inferred elsewhere in the orogen (Kvale, 1953; Hossack, 1983; Morley, 1983; Nystuen, 1983; Gayer et al., 1985; Townsend et al., 1986; Townsend, 1987; Gayer and Greiling, 1989; Gilotti, 1989; Greiling et al., 1989; Andersen et al., 1990; Fossen, 1992; Terry and Robinson, 2004). The steep lineations preserved locally-most notably in the Volda, Åndalsnes and Romsdalen domains-imply vertical thickening and may also have formed during subduction.

From 415-400 Ma continued collision carried the WGR and allochthons to UHP conditions coincident with continued thrusting in the foreland (Fig. 13b, Fossen and Dunlap, 1998). Eclogites formed across the WGR. Some of the first HP eclogites to form south of the study area (e.g., the Lindås nappe in the Bergen area south of Fig. 1a, Bingen et al., 2004) were exhumed in the hinterland at this time. The 15-20 Myr range of eclogite ages requires that the subducted WGR was thermally insulated from the hotter hanging wall mantle (Kylander-Clark et al., 2009); in Fig. 13b we speculate that this thermal blanket was the subducted allochthons.

Beginning around $400 \mathrm{Ma}$, orogen-wide transtension became dominant (Fig. 13c) (Dewey and Strachan, 2003). The distribution of eclogite isobars, the E-dipping homocline that characterizes much of the study area, the westward decrease in sphene ages, and the westward decrease in muscovite ages, indicate that the study area was progressively exhumed to crustal levels from southeast to northwest, like the WGR south of the study area (Milnes et al.,

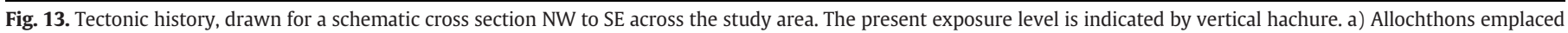

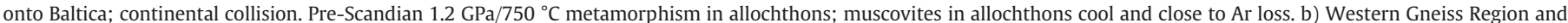

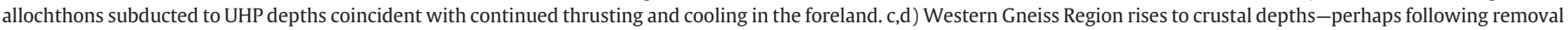

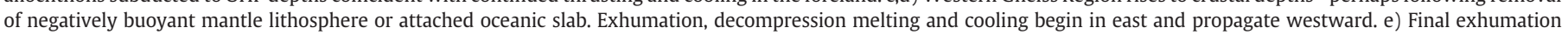
required to cool UHP domains below $400{ }^{\circ} \mathrm{C}$ occurs after 380 Ma.
} 
1997). That this exhumation was near-isothermal (Andersen and Jamtveit, 1990) implies that it was either rapid or that the HP-UHP terrane remained insulated from colder or hotter surroundings. Amphibolite-facies structures throughout most of the WGR indicate that this unroofing was accomplished by coaxial E-W extension, vertical thinning, and minor $\mathrm{N}-\mathrm{S}$ shortening. This deformation partially to completely reworked existing planar fabrics and was likely weakly constrictional (Krabbendam and Dewey, 1998; Barth et al., 2010). From 400-395 Ma, deformation in the upper $50 \mathrm{~km}$ of the orogenic belt was partitioned into discrete zones that accommodated orogen-scale E-W stretching: strong top-E shear occurred in the Bjorli and Åmotsdalen domains in the eastern part of the study area, and strong top-W shear occurred in the Nordfjord-Sogn Detachment Zone and Vågsøy domain. The backsliding or top-W extension active along the eastern edge of the WGC farther south (Andersen, 1998; Fossen, 2000) has not been observed in the study area.

By $395 \mathrm{Ma}$, the entire southern half of the WGR (everything south of the "limit of eclogite" line in Fig. 1) and the eastern third of the study area had been exhumed from pressures of 2 GPa to upper crustal depths and had cooled below $400{ }^{\circ} \mathrm{C}$. High-temperature deformation and metamorphism northwest of there, however, continued unabated. Profound decompression from 3 GPa to 0.5 GPa caused most of the gneisses in the western portion of the study area to convert to symplectite, and produced widespread decompression melting that increased in intensity northwestward. U-Pb ages on sphene indicate that this unroofing to depths of 15-20 km occurred at $398 \mathrm{Ma}$ in the central part of the study area and as late as 389 Ma in the UHP domains. Strong sinistral shear developed in the Møre-Trøndelag Fault Complex and the Nordfjord Mylonitic Shear Zone, and significant mylonite zones developed in the Stadlandet, Volda, and other western domains.

In the sinistral transtension model of Krabbendam and Dewey (1998), the Møre-Trøndelag Fault Complex marks a northward transition from vertical thinning and minor N-S shortening into a zone of minor vertical thinning and strong $\mathrm{N}-\mathrm{S}$ shortening (all with a strong E-W stretch). Dextral fabrics within the Nordfjord Mylonitic Shear Zone may represent a complementary southward transition. If so, the Møre-Trøndelag Fault Complex and the Nordfjord Mylonitic Shear Zone may be tear fault shear zones with minimal vertical thinning, that separate an intervening domain with (U)HP rocks exhumed by strong vertical thinning and E-W stretching, from weakly extended areas to the north and south.

In the central and western parts of the study area, sphene and muscovite ages differ by $4-5 \mathrm{Myr}$, implying a cooling rate of $\sim 50 \mathrm{~K} / \mathrm{Myr}$ $\left(700-800{ }^{\circ} \mathrm{C} \rightarrow 400{ }^{\circ} \mathrm{C}\right.$ ) at depths of $15-20 \mathrm{~km}$. This rapid cooling requires sudden removal of the thermal blanket that permitted the near-adiabatic ascent from the mantle. The characteristic thermal diffusion distance for 4-5 Myr is only $\sim 11-12 \mathrm{~km}$, implying that this rapid mid-crustal cooling was not accomplished solely by erosion. The E-W gradient in the muscovite ages indicates a westward propagation of this rapid cooling-all at crustal depths-over a relatively long time of $15 \mathrm{Myr}$ (400-385 Ma). In Fig. 13d we speculate that the rapid cooling might have been accomplished by westward propagation of the NSDZ across the WGR and/or by thrusting of the WGR over Baltica.

Significant deformation in the UHP domains ceased at amphibolitefacies conditions, and yet muscovite $385 \mathrm{Ma}$ and $380 \mathrm{Ma}$ chrontours clearly define SE-plunging antiforms within at least the Nordfjord and Sørøyane UHP domains (see summary in Hacker, 2007). This requires that the final stages of exhumation of the UHP domains to crustal levels cooler than $400{ }^{\circ} \mathrm{C}$ occurred by folding after $380 \mathrm{Ma}$ (Fig. 13e).

\subsection{Size and coherence of UHP terranes}

Understanding the size of UHP terranes is important, because terrane size dictates the tectonic scenario in which UHP terranes develop and thus the impact that UHP processes had on the evolution of Earth: the bigger and more coherent the terrane, the more specialized the tectonic process required and the greater the impact on Earth evolution. Stöckhert and Gerya (2005) used the i) limited size of UHP slices in the Alps, ii) the existence of UHP rocks that apparently predate continental collision, and iii) palinspastic restorations of the Alps, to conclude that UHP terranes are relatively small products of subduction erosion (cf. Hacker et al., 2005; Yin et al., 2007) rather than large portions of subducted continental margins. In contrast, the existence of (U)HP terranes in eastern China (Hacker et al., 2004) and in western Norway that exceed $30,000 \mathrm{~km}^{2}$ might, at face value, be used to conclude the opposite, unless those giant UHP terranes are actually composed of a series of smaller slices separated by large-offset shear zones.

Several observations from the study area bear on this topic. The least-deformed area is in the southeast. There, the presence of eclogites requires burial to a depth of $60 \mathrm{~km}$ or more, but the area is roughly a structural homocline with only weak Scandian deformation. Allochthons that were emplaced onto the WGR prior to the Scandian (U)HP event are relatively flat lying as far west as Tafjord ("T" in Fig. 1) (Lutro and Tveten, 1998; Tveten et al., 1998; Walsh and Hacker, 2004). The most-deformed areas are the UHP domains, particularly the Sørøyane and Nordøyane domains. Here, the juxtaposition of eclogites with pressures of $\sim 3.3 \mathrm{GPa}$ to $\sim 2.0 \mathrm{GPa}$ across distances of 15-20 km (Wain et al., 2000; Young et al., 2007), strain measured in host gneisses (Krabbendam and Dewey, 1998), and the presence of generally symmetrical structures argue for large-scale E-W stretching and vertical thinning (Labrousse et al., 2002). The HP to UHP transitions appear to be relatively smooth (Root et al., 2005; Young et al., 2007), however, implying that rocks of different pressure are not chaotically intermixed. The area between the least-deformed southeast and the most-deformed northwest is transitional, with high- and low-strain zones.

\subsection{Deformation of continental crust at high temperature $\mathcal{E}$ pressure}

The rheology of quartz and feldspar at high temperature and pressure dictate the elevation, topography, and internal dynamics of continental orogens (Dewey et al., 1993). The widespread presence of strongly deformed quartzofeldspathic gneisses (such as the WGC) on Earth's surface has led to the assumption that such rocks invariably flow at high temperatures. For example, a range of observations, including topography, heat flow, and seismic velocities, indicate that the quartzofeldspathic middle to lower crust beneath Earth's only well-studied ongoing continental collision-the Tibetan Plateau-is undergoing large-scale flow at temperatures up to $1100{ }^{\circ} \mathrm{C}$ (Hacker et al., 2000; Enkelmann et al., 2006; Klemperer, 2006). Recent models of UHP-terrane exhumation based on experimental flow laws show wholesale overturning of the exhuming (U)HP continental crust (e.g., Gerya and Stöckhert, 2006; Gerya et al., 2008; Warren et al., 2008), leading to the prediction that giant UHP terranes might be composed of diapirs that produce high strains and crustal-scale mixing.

Although the northwestern part of the study area was indeed strongly deformed during the Scandian orogeny, the southwestern part, which contains eclogite blocks and reached temperatures of $650-750^{\circ} \mathrm{C}$ (Walsh and Hacker, 2004), was not significantly deformed during subduction or exhumation. Further, the widespread presence of undeformed symplectite throughout the western $2 / 3$ of the study area indicates that there was little deformation after symplectite formation, even though this also occurred at temperatures in excess of $650{ }^{\circ} \mathrm{C}$. These findings are similar to those from the UHP Dora Maira massif, where Lenze and Stockhert (2007) reported preserved UHP microstructures in Dora Maira UHP rocks, and concluded that the bulk of the UHP terrane undeformed during exhumation. Thus, large volumes of quartzofeldspathic continental crust-regardless of mineral changes that may accompany subduction-can be subjected to high temperatures and pressures during orogeny and yet remain 
undeformed. This contrasts with models of UHP terrane formation and exhumation (see above), indicating that changes to model rheologies are required. One cannot assume that bulk continental crust flows pervasively at temperatures of $650-750{ }^{\circ} \mathrm{C}$.

\section{Conclusions}

A dataset including more than 8000 new structural measurements, many tens of sense of shear measurements, and other outcrop-scale observations is reported for the Western Gneiss Region along a $>100 \mathrm{~km}$ long swathe from the ultrahigh-pressure domains toward the foreland. The new data allow subdivision of the WGR into distinct structural and petrological domains. The bulk of the study area can be described crudely as an E-dipping homocline with $15-29^{\circ}$ E-plunging lineations that exposes deeper, more strongly deformed, more eclogiterich structural levels westward. Early structures are well preserved in the southeastern half of the study area, where-in spite of the presence of eclogites-recognizable Scandian deformation is weak. The Scandian reworking becomes progressively stronger westward, culminating in the northwest in strong Scandian fabrics with only isolated pockets of Precambrian structures; here, foliations are generally flat lying or folded about E-W axes. The dominant Scandian deformation was chiefly coaxial E-W stretching. This homocline-like feature is bounded on three sides by domains with abundant asymmetric fabrics: the sinistrally sheared Møre-Trøndelag Fault Complex to the north and the Nordfjord Mylonitic Shear Zone to the south. The eastern edge of the study area shows modest top-E, amphibolite-facies deformation associated with translation of the allochthons over the basement, and the NordfjordSogn Detachment Zone underwent strong lower amphibolite-facies to greenschist-facies top-W shearing.

Leucosomes with hornblende, plagioclase, and Scandian sphene are restricted to the northern half and western edge of the study area, indicating an increase in melting toward the northwest. In most domains, the bulk of the Scandian deformation was followed by decompression-related symplectite formation in quartzofeldspathic gneiss, and further deformation was restricted to slip along biotiterich foliation planes and minor local folding. The strong gradient in deformation observed in the quartzofeldspathic gneiss of the Western Gneiss Region implies that continental crust in general need not undergo pervasive deformation at temperatures of $650-750{ }^{\circ} \mathrm{C}$.

\section{Acknowledgments}

Funded by NSF EAR-9814889 and NSF EAR-0510453, and the Norwegian Research Council Centre of Excellence Grant to Physics of Geological Processes (PGP). This paper was reviewed by Julie Baldwin, Haakon Fossen, Matthias Konrad-Schmolke, Martin Krabbendam, and Mike Terry. Elizabeth Eide, Phil Gans, Peter Robinson, and Mike Terry made helpful suggestions over the years that this work was in progress. Stereonets plotted using Rick Almendinger's StereoWin and David Mainprice's Field2k programs.

\section{References}

Andersen, T.B., 1998. Extensional tectonics in the Caledonides of southern Norway, an overview. Tectonophysics 285, 333-351.

Andersen, T.B., Jamtveit, B., 1990. Uplift of deep crust during orogenic extensiona collapse: a model based on field studies in the Sogn-Sunnfjord region of western Norway. Tectonics 9, 1097-1111.

Andersen, T.B., Skjerlie, K.P., Furnes, H., 1990. The Sunnfjord Melange, evidence of Silurian ophiolite accretion in the West Norwegian Caledonides. Journal of the Geological Society of London 147, 59-68.

Andersen, T.B., Jamtveit, B., Dewey, J.F., Swensson, E., 1991. Subduction and eduction of continental crust: major mechanism during continent-continent collision and orogenic extensional collapse, a model based on the south Caledonides. Terra Nova 3, 303-310.

Andersen, T.B., Osmundsen, P.T., Jolivet, L., 1994. Deep crustal fabrics and a model for the extensional collapse of the southwest Norwegian Caledonides. Journal of Structural Geology 16, 1191-1203.
Austrheim, H., 1987. Eclogitization of lower crustal granulites by fluid migration through shear zones. Earth and Planetary Science Letters 81, 221-232.

Austrheim, H., Griffin, W.L., 1985. Shear deformation and eclogite formation within granulite-facies anorthosites of the Bergen Arcs, western Norway. Chemical Geology 50, 267-281.

Austrheim, H., Corfu, F., Bryhni, I., Andersen, T.B., 2003. The Proterozoic Hustad igneous complex: a low strain enclave with a key to the history of the Western Gneiss Region of Norway. Precambrian Research 120, 149-175.

Barth, N.C. et al., 2010. Strain within the ultrahigh-pressure Western Gneiss region of Norway recorded by quartz CPOs. Geological Society of London Special Publication.

Bingen, B., Davis, W.J., Austrheim, H., 2001. Zircon U-Pb geochronology in the Bergen arc eclogites and their Proterozoic protoliths, and implications for the pre-Scandian evolution of the Caledonides in western Norway. Geological Society of America Bulletin 113.

Bingen, B., Austrheim, H., Whitehouse, M.J., Davis, W.J., 2004. Trace element signature and $\mathrm{U}-\mathrm{Pb}$ geochronology of eclogite-facies zircon, Bergen Arcs, Caledonides of $\mathrm{W}$ Norway. Contributions to Mineralogy and Petrology 147, 671-683.

Braathen, A., 1999. Kinematics of post-Caledonian polyphase brittle faulting in the Sunnfjord region, western Norway. Tectonophysics 302, 99-121.

Bryhni, I., 1966. Reconnaissance studies of gneisses, ultrabasites, eclogites and anorthosites in outer Nordfjord, western Norway. Norges Geologiske Undersokelse 241, 68.

Bryhni, I., Andréasson, P.-G., 1985. Metamorphism in the Scandinavian Caledonides. In: Gee, , D.G., Sturt, B.A. (Eds.), The Caledonide Orogen-Scandinavia and Related Areas. John Wiley and Sons, Chichester, pp. 763-781.

Carswell, D.A., Cuthbert, S.J., 2003. Ultrahigh pressure metamorphism in the Western Gneiss Region of Norway. EMU Notes in Mineralogy 5, 51-73.

Chauvet, A., Séranne, M., 1989. Microtectonic evidence of Devonian extensional westward shearing in southern Norway. In: Gayer, R.A. (Ed.), The Caledonide Geology of Scandinavia. Graham and Trotman, London, pp. 245-254.

Chauvet, A., Kienast, J.R., Pinardon, J.L., Brunel, M., 1992. Petrological constraints and PT path of Devonian collapse tectonics within the Scandian mountain belt (Western Gneiss Region, Norway). Journal of the Geological Society of London $149,383-400$.

Cohen, A.S., O'Nions, R.K., Siegenthaler, R., Griffin, W.L., 1988. Chronology of the pressure-temperature history recorded by a granulite terrain. Contributions to Mineralogy and Petrology 98, 303-311.

Connolly, J.A.D., Petrini, K., 2002. An automated strategy for calculation of phase diagram sections and retrieval of rock properties as a function of physical conditions. Journal of Metamorphic Geology 20, 697-798.

Corfu, F., Andersen, T.B., 2002. U-Pb ages of the Dalsfjord Complex, SW Norway, and their bearing on the correlation of allochthonous crystalline segments of the Scandinavian Caledonides. International Journal of Earth Science 91, 955-963.

Cuthbert, S.J., Carswell, D.A., Krogh-Ravna, E.J., Wain, A., 2000. Eclogites and eclogites in the Western Gneiss Region, Norwegian Caledonides. Lithos 52, 165-195.

Dewey, J.F., Strachan, R.A., 2003. Changing Silurian-Devonian relative plate motion in the Caledonides: sinistral transpression to sinistral transtension. Journal of the Geological Society of London 160, 219-229.

Dewey, J.F., Ryan, P.D., Andersen, T.B., 1993. Orogenic uplift and collapse, crustal thickness, fabrics and metamorphic phase changes; the role of eclogites. Geological Society Special Publications 76, 325-343.

Dobrzhinetskaya, L.F., et al., 1995. Microdiamond in high-grade metamorphic rocks of the Western Gneiss region, Norway. Geology 23, 597-600.

Dransfield, M., 1994. Extensional Exhumation of High-Grade Rocks in Western Norway and the Zanskar Himalaya. University of Oxford.

Engvik, A.K., Andersen, T.B., 2000. The progressive evolution of Caledonian deformation fabrics under eclogite and amphibolite facies at Vårdalsneset, Western Gneiss Region, Norway. Journal of Metamorphic Geology 18, 241-257.

Engvik, A.K., Andersen, T.B., Wachmann, M., 2007. Inhomogeneous deformation in deeply buried continental crust, an example from the eclogite-facies province of the Western Gneiss Region. Norway. Norwegian Journal of Geology 87, 373-389.

Enkelmann, E., et al., 2006. Is Tibetan lower crustal flow diverging around the Sichuan Basin? Denudation and deformation in the Qinling. Geological Society of America Bulletin 118, 651-671.

Eskola, P., 1921. On the eclogites of Norway. Norske videnskaps-akademi i Oslo. Matematisk-naturvidenskabelig klasse 8, 118.

Foreman, R., Andersen, T.B., Wheeler, J., 2005. Eclogite-facies polyphase deformation of the Drosdal eclogite, Western Gneiss Complex, Norway, and implications for exhumation. Tectonophysics 398, 1-32.

Fossen, H., 1992. The role of extensional tectonics in the Caledonides of south Norway. Journal of Structural Geology 14, 1033-1046.

Fossen, H., 2000. Extensional tectonics in the Caledonides: synorogenic or postorogenic? Tectonics 19, 213-224.

Fossen, H., Dunlap, W.J., 1998. Timing and kinematics of Caledonian thrusting and extension collapse, southern Norway; evidence from $40 \mathrm{Ar} / 39 \mathrm{Ar}$ thermochronology. Journal of Structural Geology 20, 765-781.

Gayer, R.A., Greiling, R.O., 1989. Caledonian nappe geometry in north-central Sweden and basin evolution on the Baltoscandian margin. Geological Magazine 126, 499-413.

Gayer, R.A., Hayes, S.J., Rice, A.H.N., 1985. The structural development of the Kalak nappe complex of eastern and central Porsangerhalvoya, Finnmark, Norway. Norges Geologiske Undersogelse 400, 67-87.

Gee, D.G., 1975. A tectonic model for the central part of the Scandinavian Caledonides. American Journal of Science 275-A, 468-515.

Gee, D.G., 1980. Basement-cover relationships in the central Scandinavian Caledonides. Geologiska Föreningens i Stockholm Förhandlingar 102, 455-474. 
Gerya, T.V., Stöckhert, B., 2006. Two-dimensional numerical modeling of tectonic and metamorphic histories at active continental margins. International Journal of Earth Sciences 95, 250-274.

Gerya, T.V., Perchuk, L.L., Burg, J.-P., 2008. Transient hot channels: perpetrating and regurgitating ultrahigh-pressure, high temperature crust-mantle associations in collision belts. Lithos 103, 236-256.

Gilotti, J.A., 1989. Reaction progress during mylonitization of basaltic dikes along the Sarv Thrust, Swedish Caledonides. Contributions to Mineralogy and Petrology 101 (1), 30-45.

Gjelsvik, T., 1951. Oversikt over bergartene på Sunnmøre og tilgrensende deler av Nordfjord. Med geologisk oversiktskart av T. Gjelsvik \& Chr. C. Gleditsch. Norges Geologiske Undersøkelse 179, 1-45.

Glodny, J., Kühn, A., Austrheim, H., 2008. Diffusion versus recrystallization processes in $\mathrm{Rb}-\mathrm{Sr}$ geochronology: isotopic relics in eclogite facies rocks, Western Gneiss Region, Norway. Geochimica et Cosmochimica Acta 72, 506-525.

Greiling, R.O., Kaus, A., Leipziger, 1989. A Seve duplex (Upper Allochthon) at the northern margin of the Grong district (Caledonides of central Norway). Norsk Geologisk Tidsskrift 69, 83-93.

Grønlie, A., Roberts, D., 1989. Resurgent strike-slip duplex development along the Hitra-Snasa and Verran faults, More-Trondelag fault zone, central Norway. Journal of Structural Geology 11, 295-305.

Hacker, B.R., 2006. Pressures and temperatures of ultrahigh-pressure metamorphism: implications for UHP tectonics and $\mathrm{H} 2 \mathrm{O}$ in subducting slabs. International Geology Review 48, 1053-1066.

Hacker, B.R., 2007. Ascent of the ultrahigh-pressure Western Gneiss Region, Norway. In: Cloos, M., Carlson, W.D., Gilbert, M.C., Liou, J.G., Sorenson, S.S. (Eds.), Convergent Margin Terranes and Associated Regions: A Tribute to W.G. Ernst. Geological Society of America Special Paper. Geological Society of America, Boulder, CO, pp. 171-184.

Hacker, B.R., Gans, P.B., 2005. Creation of ultrahigh-pressure terranes: the TrondelagJämtland region of the Scandinavian Caledonides. Geological Society of America Bulletin 117, 117-134.

Hacker, B.R., et al., 2000. Hot and dry xenoliths from the lower crust of Tibet. Science 287, 2463-2466.

Hacker, B.R., et al., 2003a. Exhumation of high-pressure rocks beneath the Solund Basin, Western Gneiss Region of Norway. Journal of Metamorphic Geology 21, 613-629.

Hacker, B.R., et al., 2003b. Exhumation of high-pressure rocks beneath the Solund Basin, Western Gneiss region of Norway. Journal of Metamorphic Geology 21 (6), 613-629.

Hacker, B.R., Ratschbacher, L., Liou, J.G., 2004. Subduction, collision, and exhumation in the Qinling-Dabie Orogen. In: Malpas, J.G., Fletcher, C.J.N., Ali, J.R., Aitchison, J.C. (Eds.), Aspects of the Tectonic Evolution of China. Geological Society of London Special Publication, pp. 157-175.

Hacker, B.R., et al., 2005. Near-ultrahigh pressure processing of continental crust: Miocene crustal xenoliths from the Pamir. Journal of Petrology 46, 1661-1687.

Heinrich, C.H., 1982. Kyanite-eclogite to amphibolite facies evolution of hydrous mafic and pelitic rocks, Adula nappe, central Alps. Contributions to Mineralogy and Petrology 81, 30-38.

Hossack, J.R., 1983. A cross-section through the Scandinavian Caledonides constructed with the aid of branchline maps. Journal of Structural Geology 5, 103-111.

John, T., Medvedev, M., Rüpke, L.H., Andersen, T.B., Podladchikov, Y.Y., Austrheim, H. 2009. Generation of intermediate-depth earthquakes by self-localizing thermal runaway. Nature Geoscience 2, 137-140. doi:10.1038/NGEO419.

Johnston, S., Hacker, B.R., Andersen, T.B., 2007a. Exhuming Norwegian ultrahighpressure rocks: overprinting extensional structures and the role of the NordfjordSogn Detachment Zone. Tectonics 26, TC5001. doi:10.1029/2005TC001933.

Johnston, S., Hacker, B.R., Ducea, M.N., 2007b. Exhumation of ultrahigh-pressure rocks beneath the Hornelen segment of the Nordfjord-Sogn Detachment Zone, western Norway. Geological Society of America Bulletin 119, 1232-1248.

Jolivet, L., et al., 2005. Softening trigerred by eclogitization, the first step toward exhumation during continental subduction. Earth and Planetary Science Letters 237, 532-547.

Klemperer, S., 2006. Crustal flow in Tibet: geophysical evidence for the physical state of Tibetan lithosphere, and inferred patterns of active flow. In: Law, R.D., Searle, M. and Godin, L. (Editors), Channel Flow, Ductile Extrusion and Exhumation in Continental Collision Zones. Geological Society, London, Special Publications, London, pp. 39-70.

Krabbendam, M., Wain, A., 1997. Late-Caledonian structures, differential retrogression and structural position of (ultra) high pressure rocks in the Nordfjord-Stadtlandet area, Western Gneiss Region. Norges Geologiske Undersøkelse Bulletin 432 127-139.

Krabbendam, M., Dewey, J.F., 1998. Exhumation of UHP rocks by transtension in the Western Gneiss Region, Scandinavian Caledonides. In: Holdsworth, R.E.S., R A, Dewey, J.F. (Eds.), Continental transpressional and transtensional tectonics, Geological Society Special Publications. Geological Society of London, London, pp. 159-181.

Krabbendam, M., Wain, A., Andersen, T.B., 2000. Pre-Caledonian granulite and gabbro enclaves in the Western Gneiss Region, Norway: indications of incomplete transition at high pressure. Geological Magazine 137, 235-255.

Krill, A.G., 1980. Tectonics of the Oppdal area, central Norway. Geologiska Föreningens i Stockholm Förhandlingar 102, 523-530.

Krogh, E.J., 1977. Evidence of Precambrian continent-continent collision in Western Norway. Nature 267, 17-19.

Krogh, E.J., 1980. Compatible P-T conditions for eclogites and surrounding gneisses in the Kristiansund area, western Norway. Contributions to Mineralogy and Petrology 75, 387-393.

Kühn, A., Glodny, J., Iden, K., Austrheim, H., 2000. Retention of Precambrian RbrSr phlogopite ages through Caledonian eclogite facies metamorphism, Bergen Arc Complex, W-Norway. Lithos 51, 305-330.
Kvale, A., 1953. Linear structures and their relation to movements in the Caledonides of Scandinavia and Scotland. Journal of the Geological Society of London 109, 51-73.

Kylander-Clark, A.R.C., et al., 2007. Timing of multi-stage metamorphism during ultrahigh-pressure continental subduction and exhumation: $\mathrm{Lu} / \mathrm{Hf}$ and $\mathrm{Sm} / \mathrm{Nd}$ geochronology in western Norway. Chemical Geology 232, 137-154.

Kylander-Clark, A.R.C., Hacker, B.R., Mattinson, J.M., 2008. Slow exhumation of UHP terranes: titanite and rutile ages of the Western Gneiss Region, Norway. Earth and Planetary Science Letters 272, 531-540.

Kylander-Clark, A.R.C., Hacker, B.R., Johnson, C.M., Beard, B.L., Mahlen, N.J., 2009. Slow subduction of a thick ultrahigh-pressure terrane. Tectonics 23, TC2003. doi:10.1029/2007TC002251.

Labrousse, L., Jolivet, L., Agard, P., Hébert, R., Andersen, T.B., 2002. Crustal-scale boudinage and migmatization of gneiss during their exhumation in the UHP Province of Western Norway. Terra Nova 14, 263-270.

Labrousse, L., et al., 2004. Pressure-temperature-time-deformation history of the exhumation of ultra-high pressure rocks in the Western Gneiss region, Norway. In: Whitney, D.L., Teyssier, C., Siddoway, C.S. (Eds.), Gneiss Domes in Orogeny, Geological Society of America Special Paper. Geological Society of America, pp. 155-185.

Lappin, M.A., Smith, D.C., 1978. Mantle-equilibrated orthopyroxene eclogite pods from the basal gneisses in the Selje District, western Norway. Journal of Petrology 19 530-584.

Lenze, A., Stöckhert, B., 2007. Microfabrics of UHP metamorphic granites in the Dora Maira Massif, western Alps-no evidence of deformation at great depth. Journal of Metamorphic Geology 25, 461-475

Lister, G.S., Dornsiepen, U.F., 1982. Fabric transitions in the Saxony granulite terrain. Journal of Structural Geology 11, 65-94.

Lund, M.G., Austrheim, H., 2003. High-pressure metamorphism and deep-crusta seismicity; evidence from contemporaneous formation of pseudotachylytes and eclogite facies coronas. Tectonophysics 372 (1-2), 59-83.

Lundmark, A.M., Corfu, F., 2008. Emplacement of a Silurian granitic dyke swarm during nappe translation in the Scandinavian Caledonides. Journal of Structural Geology 30, 918-928.

Lutro, O., Tveten, E., 1998. Geologisk kart over Noreg, berggrunskart ÅRDAL. Noregs Geologiske Undersøkning.

Mainprice, D., 2005. Pfch5 [Computer software]. In: ftp://www.gm.univ-montp2.fr/ mainprice//CareWare_Unicef_Programs/(Editor).

Medaris Jr, L.G., 1984. A geothermobarometric investigation of garnet peridotites in the Western Gneiss Region of Norway. Contributions to Mineralogy and Petrology 87, 72-86.

Milnes, A.G., Wennberg, O.P., Skår, Ø., Koestler, A.G., 1997. Contraction, extension, and timing in the South Norwegian Caledonides: the Sognefjord transect. In: Burr, J.-P., Ford, M. (Eds.), Orogeny Through Time. Geological Society of London Special Publication, pp. 123-148.

Mørk, M.B.E., 1985. Incomplete high P-T metamorphic transitions within the Kvamsøy pyroxenite complex, west Norway: a case study of disequilibrium. Journal of Metamorphic Geology 3, 245-264.

Morley, C.K., 1983. The Structural Geology of the Southern Norwegian Caledonides in the Oslo Graben and Sparagmite Regions. City of London Polytechnic.

Mysen, B.O., Heier, K.S., 1971. A note on the field occurrence of a large eclogite on Hareid Sunnmoere, western Norway, Norsk Geologisk Tidsskrift 50, 93-96 Supplement.

Norton, M.G., 1987. The Nordfjord-Sogn detachment, W. Norway. Norsk Geologisk Tidsskrift 67, 93-106.

Nystuen, J.P., 1983. Nappe and thrust structures in the Sparagmite region southern Norway. Norges Geologiske Undersogelse 380, 67-83.

Peterman, E.M., Hacker, B.R. and Baxter, E.F., in press. Phase transformations of continental crust during subduction and exhumation: Western Gneiss Region, Norway. European Journal of Mineralogy.

Ravna, E.J.K., Terry, M.P., 2004. Geothermobarometry of phengite-kyanite-quartz/ coesite eclogites. Journal of Metamorphic Geology 22, 579-592.

Robinson, P., 1995. Extension of Trollheimen tectono-stratigraphic sequence in deep synclines near Molde and Brattvåg, Western Gneiss Region, southern Norway. Norsk Geologisk Tidsskrift 75, 181-198.

Røhr, T.S., Corfu, F., Austrheim, H., Andersen, T.B., 2004. Sveconorwegian U-Pb zircon and monazite ages of granulite-facies rocks, Hisarøya Gulen, Western Gneiss Region, Norway. Norwegian Journal of Geology 84, 251-256.

Root, D.B., Hacker, B.R., Mattinson, J.M., Wooden, J.L., 2004. Young age and rapid exhumation of Norwegian ultrahigh-pressure rocks: an ion microprobe and chemical abrasion study. Earth and Planetary Science Letters 228, 325-341.

Root, D.B., et al., 2005. High-pressure allochthons overlie the ultrahigh-pressure Western Gneiss Region, Norway. Journal of Metamorphic Geology 23, 45-61.

Séranne, M., 1992. Late Palaeozoic kinematics of the Møre-Trøndelag fault zone and adjacent areas, central Norway. Norsk Geologisk Tidsskrift 72, 141-158.

Skår, Ø., Pedersen, R.B., 2003. Relations between granitoid magmatism and migmatization: $\mathrm{U}-\mathrm{Pb}$ geochronological evidence from the Western Gneiss Complex, Norway. Journal of the Geological Society of London 160, 935-946.

Smith, D.C., 1984. Coesite in clinopyroxene in the Caledonides and its implications for geodynamics. Nature 310, 641-644.

Stöckhert, B., Gerya, T.V., 2005. Pre-collisional high pressure metamorphism and nappe tectonics at active continental margins: a numerical simulation. Terra Nova 17 , $102-110$.

Straume, Å.K., Austrheim, H., 1999. Importance of fracturing during retro-metamorphism of eclogites. Journal of Metamorphic Geology 17, 637-652.

Terry, M.P., Robinson, P., 2003. Evolution of amphibolite-facies structural features and boundary conditions for deformation during exhumation of high- and ultrahighpressure rocks, Nordøyane, Western Gneiss Region, Norway. Tectonics 22, 1036 doi:10.1029/2001TC001349. 
Terry, M.P., Robinson, P., 2004. Geometry of eclogite-facies structural features: implications for production and exhumation of UHP and HP rocks, Western Gneiss Region, Norway. Tectonics 23. doi:10.1029/2002TC001401.

Terry, M.P., Robinson, P., Hamilton, M.A., Jercinovic, M.J., 2000a. Monazite geochronology of UHP and HP metamorphism, deformation, and exhumation, Nordøyane, Western Gneiss Region, Norway. American Mineralogist 85, 1651-1664.

Terry, M.P., Robinson, P., Ravna, E.J.K., 2000b. Kyanite eclogite thermobarometry and evidence for thrusting of UHP over HP metamorphic rocks, Nordøyane, Western Gneiss Region, Norway. American Mineralogist 85, 1637-1650.

Townsend, C., 1987. Thrust transport directions and thrust sheet restoration in the Caledonides of Finnmark, North Norway. Journal of Structural Geology 9, 345-352.

Townsend, C., Roberts, D., Rice, A.H.N., Gayer, R.A., 1986. The Gaissa Nappe, Finnmark, North Norway; an example of a deeply eroded external imbricate zone within the Scandinavian Caledonides. Journal of Structural Geology 8, 431-440.

Tucker, R.D. Krogh, T.E, Råheim, A, 1990. Proterozoic evolution and age-province boundaries in the central part of the Western Gneiss region, Norway: results of $\mathrm{U}-\mathrm{Pb}$ dating of accessory minerals from Trondheimsfjord to Geiranger. In: Gower, C.F., River, T., Ryan, B. (Eds.), Mid-Proterozoic Laurentia-Baltica. GAC special paper. Geological Association of Canada, St. John's (Newfoundland, pp. 149-173.

Tucker, R.D., et al., 2004. Thrusting and extension in the Scandian hinterland, Norway: new $\mathrm{U}-\mathrm{Pb}$ ages and tectonostratigraphic evidence. American Journal of Science 304, 477-532.

Tveten, E., Lutro, O., Thorsnes, T., 1998. Geologisk kart over Noreg, berggrunskart ÅLESUND. Noregs Geologiske Undersøkning.

Vrijmoed, J.C., Van Roermund, H.L.M., Davies, G.R., 2006. Evidence for diamond-grade ultra-high pressure metamorphism and fluid interaction in the Svartberget Fe-Ti garnet peridotite-websterite body, Western Gneiss Region, Norway. Mineralogy and Petrology 88, 381-405.
Wain, A., 1997. Ultrahigh Pressure Metamorphism in the Western Gneiss region, Norway: Excursion in the Nordfjord-Stadtlandet UHP Province. 6 pp. plus figures. Wain, A., Waters, D., Jephcoat, A., Olijnyk, H., 2000. The high-pressure to ultrahighpressure transition in the Western Gneiss Region, Norway. European Journal of Mineralogy 12, 667-687.

Wain, A., Waters, D., Austrheim, H., 2001. Metastability of granulites and processes of eclogitization in the UHP region of western Norway. Journal of Metamorphic Geology 19, 609-625.

Walsh, E.O., Hacker, B.R., 2004. The fate of subducted continental margins: two-stage exhumation of the high-pressure to ultrahigh-pressure Western Gneiss complex, Norway. Journal of Metamorphic Geology 22, 671-689.

Walsh, E.O. et al., in review. Late exhumation of the ultrahigh-pressure Western Gneiss Region: Structural geology and structural petrology. Tectonophysics.

Walsh, E.O., Hacker, B.R., Grove, M., Gans, P.B., Gehrels, G., 2007. Timing the exhumation of (ultra)high-pressure rocks across the Western Gneiss Region, Norway. Geological Society of America Bulletin 119, 289-301.

Warren, C.J., Beaumont, C., Jamieson, R.A., 2008. Formation and exhumation of ultrahigh-pressure rocks during continental collision: role of detachment in the subduction channel. Geochemistry, Geophysics, Geosystems 9, Q04019. doi:10.1029/ 2007GC001839.

Yin, A., et al., 2007. Early Paleozoic tectonic and thermomechanical evolution of ultrahigh-pressure (UHP) metamorphic rocks in the northern Tibetan Plateau, northwest China. International Geology Review 49, 681-716.

Young, D.J., et al., 2007. Amphibolite to ultrahigh-pressure transition in western Norway: implications for exhumation tectonics. Tectonics 26, TC1007. doi:10.1029/ 2004TC001781. 